\title{
MAESPA: a model to study interactions between water limitation, environmental drivers and vegetation function at tree and stand levels, with an example application to $\left[\mathrm{CO}_{2}\right] \times$ drought interactions
}

\author{
R. A. Duursma ${ }^{1}$ and B. E. Medlyn ${ }^{2}$ \\ ${ }^{1}$ Hawkesbury Institute for the Environment, University of Western Sydney, Locked Bag 1797, Penrith, NSW 2751, Australia \\ ${ }^{2}$ Department of Biological Sciences, Macquarie University, North Ryde, NSW 2109, Australia
}

Correspondence to: R. A. Duursma (remkoduursma@gmail.com)

Received: 8 December 2011 - Published in Geosci. Model Dev. Discuss.: 17 February 2012

Revised: 5 June 2012 - Accepted: 8 June 2012 - Published: 5 July 2012

\begin{abstract}
Process-based models (PBMs) of vegetation function can be used to interpret and integrate experimental results. Water limitation to plant carbon uptake is a highly uncertain process in the context of environmental change, and many experiments have been carried out that study drought limitations to vegetation function at spatial scales from seedlings to entire canopies. What is lacking in the synthesis of these experiments is a quantitative tool incorporating a detailed mechanistic representation of the water balance that can be used to integrate and analyse experimental results at scales of both the whole-plant and the forest canopy. To fill this gap, we developed an individual treebased model (MAESPA), largely based on combining the well-known MAESTRA and SPA ecosystem models. The model includes a hydraulically-based model of stomatal conductance, root water uptake routines, drainage, infiltration, runoff and canopy interception, as well as detailed radiation interception and leaf physiology routines from the MAESTRA model. The model can be applied both to single plants of arbitrary size and shape, as well as stands of trees. The utility of this model is demonstrated by studying the interaction between elevated $\left[\mathrm{CO}_{2}\right]\left(\mathrm{e} \mathrm{C}_{\mathrm{a}}\right)$ and drought. Based on theory, this interaction is generally expected to be positive, so that plants growing in e $C_{\mathrm{a}}$ should be less susceptible to drought. Experimental results, however, are varied. We apply the model to a previously published experiment on droughted cherry, and show that changes in plant parameters due to long-term growth at e $C_{\mathrm{a}}$ (acclimation) may strongly affect the outcome of $C_{\mathrm{a}} \times$ drought experiments. We discuss potential applications of MAESPA and some of the key uncertainties in process representation.
\end{abstract}

\section{Introduction}

The response of plant carbon uptake and water use to environmental change is complex because there are many interactions and feedbacks that modify the response to single environmental drivers. This complexity is highlighted by the remarkable diversity of experimental outcomes, for example in the response of plant water use and carbon uptake to elevated atmospheric $\left[\mathrm{CO}_{2}\right]$ (Ainsworth and Long, 2005; Ainsworth and Rogers, 2007; Norby et al., 1999), warming (Rustad et al., 2001), and soil water deficit (Manzoni et al., 2011; Wu et al., 2011). Soil water availability frequently limits plant productivity, but because of interactions with plant properties, and with other environmental drivers, it remains difficult to predict the effect on vegetation water use and carbon uptake (Hanson et al., 2004). Because soil drought is already becoming more frequent as a result of climate change (Huntington, 2006), it is crucial that its effect on vegetation function is more readily quantifiable.

Process-based models (PBMs) can be used as a research tool to clarify interactions among environmental drivers, plant and canopy structure, leaf physiology and soil water availability and their combined effects on water use and carbon uptake (Luo et al., 2008; Norby and Luo, 2004; Williams et al., 2001b). Because PBMs summarize the state-of-art theory of plant functioning in a coherent quantitative framework, they provide a way forward for testing our understanding of how plants respond to environmental change. In this way, they might be used to improve on empirical metaanalyses of experiments. These meta-analyses have been crucial in determining overall responses of vegetation to manipulation of the environment, but the variability among

Published by Copernicus Publications on behalf of the European Geosciences Union. 
experiments remains incompletely understood (Poorter and Navas, 2003). Meta-analyses usually focus on the effect of a single variable on vegetation function, although it has been recognized that interactions, feedbacks and acclimation are important in determining overall experimental outcomes (Norby and Luo, 2004; Norby et al., 1999; Wullschleger et al., 2002).

Typical experiments or long-term observations are conducted at spatial scales from whole plants (potted seedlings, whole-tree chambers) to entire canopies (eddy-covariance sites, free-air $\mathrm{CO}_{2}$ enrichment; FACE). A useful PBM to analyse and integrate experiments should therefore operate at both whole-plant and canopy scales. Another requirement is that the PBM incorporate detailed water balance routines and hydraulics of the soil-plant pathway.

Currently, no PBM exists that meets both requirements, and is sufficiently detailed to allow a connection with typical measurements of plant physiological function and plant canopy structure. Here, we introduce a new model, MAESPA, based on a combination of the well-known MAESTRA and SPA models.

The MAESTRA model is a tree array model that uses detailed radiative transfer calculations and leaf physiology to calculate radiation absorption, photosynthesis and transpiration of individual trees, growing singly or in a population (Medlyn, 2004; Wang and Jarvis, 1990). The MAESTRA model has been applied in a wide range of contexts from horticulture (e.g. Bauerle and Bowden, 2011) to regional climate change (e.g. Luxmoore et al., 2000), resulting in well over fifty publications (Medlyn, 2004; updated bibliography available at www.bio.mq.edu.au/maestra/bibliog.html). A major limitation of this model, however, has been the lack of a dynamic water balance. Medlyn et al. (2005) added the capacity to input soil moisture and thereby estimate the effect of a given soil moisture stress on photosynthesis and transpiration (e.g. as used by Reynolds et al., 2009), but the model does not calculate the soil moisture dynamically. This lack severely limits model applications in dry conditions because feedbacks to plant performance via soil moisture cannot be simulated. For example, although the model has often been used to estimate effects of elevated atmospheric $\left[\mathrm{CO}_{2}\right]\left(C_{\mathrm{a}}\right)$ on canopy performance (e.g. Kirschbaum et al., 1994; Medlyn, 1996; Kruijt et al., 1999; Luo et al., 2001), the model cannot be used to investigate elevated $\left[\mathrm{CO}_{2}\right]$ impacts in drought conditions because it is not possible to calculate how elevated $\left[\mathrm{CO}_{2}\right]$ modifies soil moisture.

The SPA model (Williams et al., 2001a, b) is another well-known process-based model, with a focus on the impacts of water availability on forest canopies. However, this model is also limited in that it assumes a horizontally homogenous canopy and thus does not allow for applications to individual trees. We added to MAESTRA the detailed soil water balance routines from the SPA model (Williams et al., 2001a, b), thus combining the strengths of the two models into a new soil-plant-atmosphere model that accounts for non-homogenous stand structure. In addition, we made a number of improvements to the combined model that allow a detailed physiologically-based analysis of the complete soilplant-atmosphere pathway. We believe that the new, combined model is a significant advance over either MAESTRA or SPA and will prove a useful tool for researchers in forest ecophysiology. Our goals in this paper are to fully document the new model and to demonstrate its use by applying it to a previously intractable question, namely the interaction between atmospheric $\left[\mathrm{CO}_{2}\right]\left(C_{\mathrm{a}}\right)$ and drought.

Numerous experiments have been carried out on the interaction of $C_{\mathrm{a}}$ and drought on plant functioning (see reviews by Rogers et al., 1994 and Wullschleger et al., 2002). A simple prediction for this interaction is that the $C_{\mathrm{a}}$ response will be higher under soil drought for two reasons: firstly, lower leaflevel water use under $C_{\mathrm{a}}$ (Eamus, 1991; Medlyn et al., 2001) leads to higher soil water content, which helps plants avoid soil water deficits; and secondly, lower intercellular $\mathrm{CO}_{2}$ concentration $\left(C_{\mathrm{i}}\right)$ during drought enhances the $C_{\mathrm{a}}$ response because of the non-linear response of photosynthetic rate to $C_{\mathrm{i}}$ (Grossman-Clarke et al., 2001; McMurtrie et al., 2008). While both mechanisms have been confirmed in a number of crop and grassland studies (e.g. Morgan et al., 2004; Rogers et al., 1994), experiments with potted tree seedlings, trees in whole-tree chambers or entire canopies in FACE experiments have yielded highly variable results (Gunderson et al., 2002; Nowak et al., 2004; Warren et al., 2010; Duursma et al., 2011). Two mechanisms are likely responsible for this variability in experimental outcomes: feedbacks from e $C_{\mathrm{a}^{-}}$ induced changes in plant size on water use and soil water balance; and acclimation of leaf physiology to long-term growth at $\mathrm{e} C_{\mathrm{a}}$. We first study the response of plant carbon uptake and water use to a simulated dry-down, which is a useful baseline for comparison with actual experimental outcomes. We then study the effects of acclimation of two leaf physiology parameters on the $C_{\mathrm{a}} \times$ drought interaction. Finally, we apply the MAESPA model to a $C_{\mathrm{a}} \times$ drought experiment where a feedback of increased leaf area in the $C_{\mathrm{a}}$ treatment confounds the direct effect of $C_{\mathrm{a}}$, and show how analysis of experimental data within a model-based framework can extend basic empirical results.

\section{Methods}

\subsection{Model description}

\subsubsection{Overview}

In the following, we describe the MAESPA model, which is largely the product of the above-ground components of the MAESTRA model (Wang and Jarvis, 1990; Medlyn et al., 2007) and the water balance components of the SPA model (Williams et al., 2001a, b), with several modifications and additions (see Table 1). The MAESTRA model has its roots in 


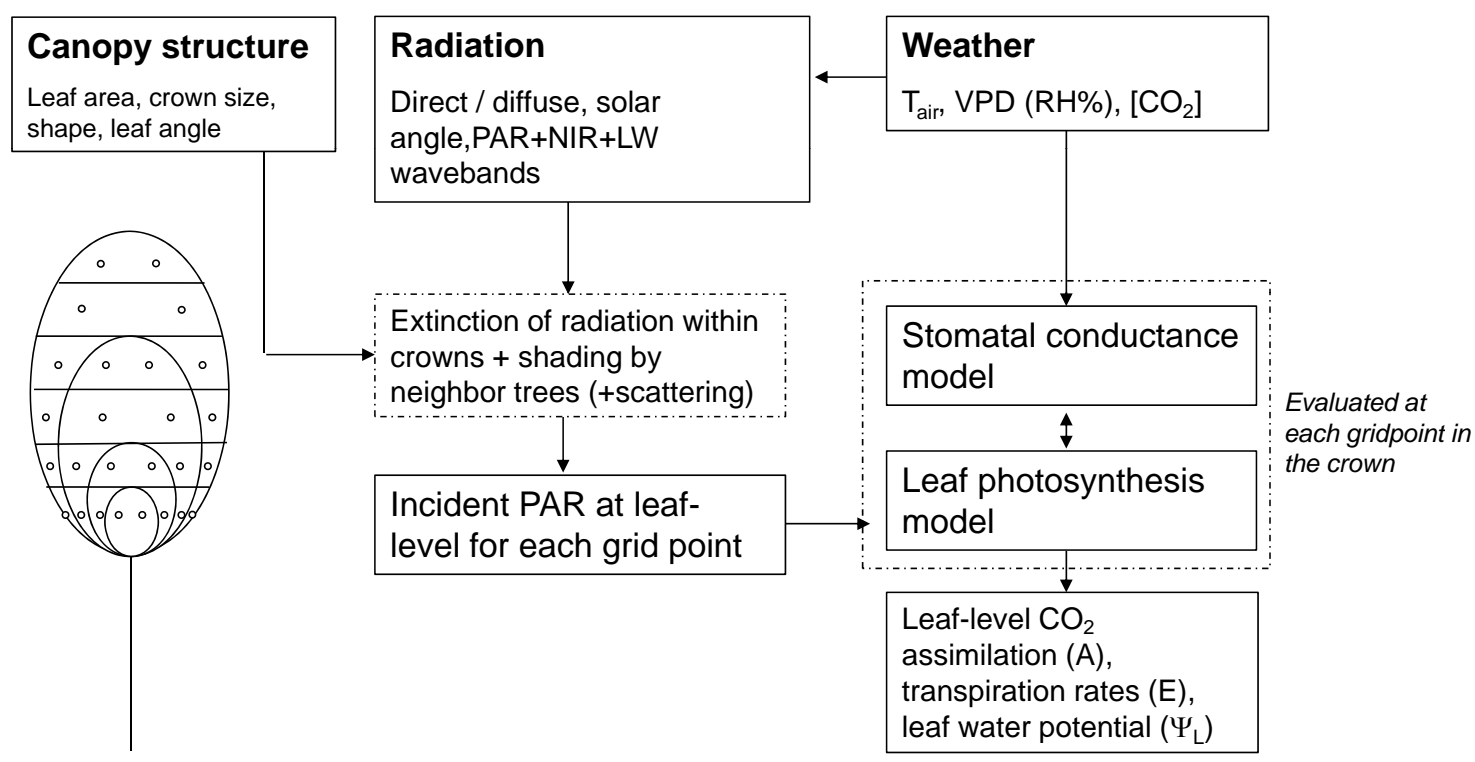

Fig. 1. Flowchart of MAESTRA, the above-ground model of the MAESPA model. Radiative transfer is calculated to a number of gridpoints (typically 72) in each target tree, which is used to drive the stomatal conductance and photosynthesis submodels. These leaf-level rates are then used to estimate whole-stand water use and carbon uptake (see Sect. "Total canopy transpiration").

an early study on radiative transfer by Norman and Welles (1983), and solidified by Wang and Jarvis, (1990). Since then, many improvements have been made, in particular the leaf gas exchange calculations (Medlyn, 1996, 2004; Medlyn et al., 2007), and the overall organization and dissemination of the code (see http://www.bio.mq.edu.au/maestra/, hereafter referred to as "the MAESTRA website"). Our goal was to widen the applicability of the MAESTRA model by including detailed soil water balance routines and plant hydraulic constraints on gas exchange.

A basic overview of how MAESTRA estimates $\mathrm{H}_{2} \mathrm{O}$ and $\mathrm{CO}_{2}$ exchange is given in Fig. 1. The processes included in the water balance sub-model are illustrated in Fig. 2. A full list of symbols is presented in Appendix A.

The MAESPA model, like MAESTRA and SPA, runs at typically a half-hourly time-step, although it can also be run at hourly or shorter arbitrary time-steps (up to every minute).

\subsubsection{Canopy processes}

Here, we provide a brief description of the canopy processes represented in MAESPA, which are largely unchanged from the original MAESTRA model (with the exception of stomatal conductance). Our goal is not to provide an in-depth description of the entire MAESTRA model (see Wang and Jarvis, 1990; Medlyn, 2004; Medlyn et al., 2007 and the detailed manual on the MAESTRA website).

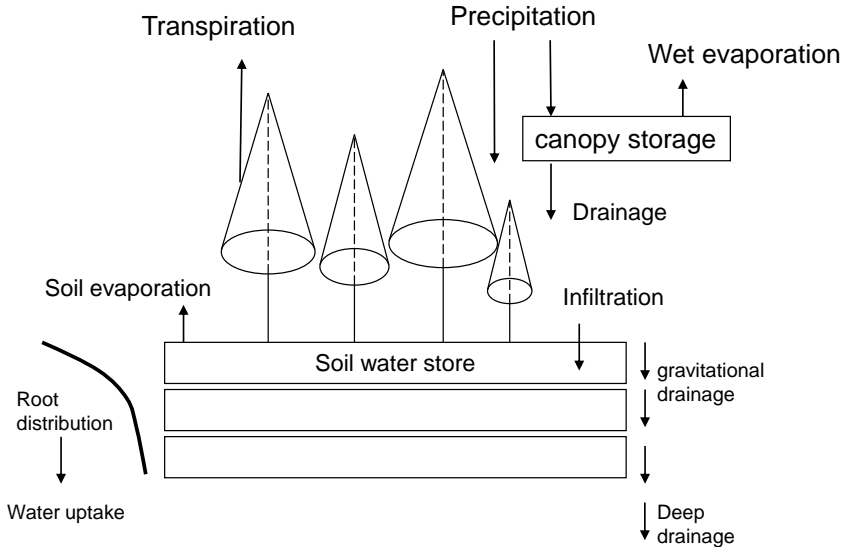

Fig. 2. Flowchart of the water balance components of MAESPA, which are taken from the SPA model. The soil compartment is horizontally homogenous, and vertically divided into an arbitrary number of layers.

\section{Radiative transfer}

The radiation routines are described in detail by Wang and Jarvis (1990). The canopy consists of individual tree crowns, which are described by a basic shape (one of several shapes, including ellipsoids, cylinders and cones), length, height to crown base, and width (in $\mathrm{x}$ and y directions). Radiation calculations are performed only for a set of target crowns specified by the user (see Sect. "Total canopy transpiration"). A number of grid points are located in a target crown, and radiation (PPFD, NIR and long-wave) at those grid points is 
Table 1. Summary of origin of the various components of the MAESPA model. For the many references for the components of the MAESTRA model, see Sects. 2.1.1 and 2.1.2, and the MAESTRA website. For the components taken from SPA, see Williams et al. (2001a, b) for the sources of those components, or the corresponding sections in the main text.

\begin{tabular}{|c|c|}
\hline Model component & Source \\
\hline Radiative transfer & MAESTRA \\
\hline Leaf energy balance & “ \\
\hline Leaf photosynthesis & “ \\
\hline Stomatal conductance $\left(g_{\mathrm{S}}\right)$, leaf and canopy transpiration & “ \\
\hline Additional models for $g_{\mathrm{s}}$ & Tuzet et al. (2003); Medlyn et al. (2011) \\
\hline Canopy interception & SPA \\
\hline Soil drainage & “ \\
\hline Soil evaporation & “ \\
\hline Soil surface energy balance & “ \\
\hline Soil temperature profile & “ \\
\hline Soil water balance & “ \\
\hline Infiltration & BROOK90; Federer et al. (2003) \\
\hline Root water uptake & Modified from SPA; Taylor and Keppler (1975) \\
\hline Soil water retention and hydraulic conductivity & Campbell (1974) \\
\hline
\end{tabular}

calculated based on shading within the crown, shading by neighbouring trees, the location of the sun, and whether radiation is direct or diffuse. Scattering of radiation is approximated following Norman (1979). Leaf area within crowns is assumed to be distributed randomly, or to follow a betadistribution in horizontal and/or vertical directions (Wang et al., 1990). At each grid point, leaf area is separated into sunlit and shaded leaf area (Norman, 1993), and the coupled stomatal conductance - photosynthesis model is run separately for each fraction (Fig. 1).

\section{Photosynthesis}

For each grid point in the crown, leaf net photosynthesis is modelled using the standard model of Farquhar et al. (1980).

$A_{\mathrm{n}}=\min \left(A_{c}, A_{j}\right)-R_{\mathrm{d}}$

where $A_{c}$ is the gross photosynthesis rate when Rubisco activity is limiting, $A_{j}$ when RuBP-regeneration is limiting, and $R_{\mathrm{d}}$ the rate of dark respiration. $A_{c}$ and $A_{j}$ are saturating functions of the intercellular $\mathrm{CO}_{2}$ concentration $\left(C_{\mathrm{i}}\right)$, both of the form $k_{1}\left(C_{\mathrm{i}}-\Gamma^{*}\right) /\left(k_{2}+C_{\mathrm{i}}\right)$, where $\Gamma^{*}$ is the $\mathrm{CO}_{2}$ compensation point without $R_{\mathrm{d}}$, and $k_{1}$ and $k_{2}$ are different parameter combinations for $A_{c}$ and $A_{j}$. The details of these functions and the temperature dependence of the parameters are described elsewhere (e.g. Medlyn et al., 2002).

\section{Stomatal conductance}

For each grid point in the crown, leaf-level stomatal conductance to $\mathrm{H}_{2} \mathrm{O}\left(g_{\mathrm{s}}\right)$ is modelled using a Ball-Berry type approach (Ball et al., 1987) (Eq. 2).

$g_{\mathrm{s}}=g_{0}+g_{1} \frac{A_{\mathrm{n}}}{C_{\mathrm{s}}} \times f(D)$ where $A_{\mathrm{n}}$ is the leaf net assimilation rate $\left(\mu \mathrm{mol} \mathrm{m}{ }^{-2} \mathrm{~s}^{-1}\right)$, $g_{0}$ the conductance when $A_{\mathrm{n}}$ is zero, $g_{1}$ an empirical parameter, $f(D)$ a function of the leaf-to-air vapour pressure deficit $(D)$ and $C_{\mathrm{s}}$ the $\mathrm{CO}_{2}$ concentration at the leaf surface $\left(\mu \mathrm{mol} \mathrm{mol}{ }^{-1}\right)$ (which is corrected for boundary layer effects, but this is usually a small correction).

We have implemented a number of options for the $f(D)$ function, including the Ball-Berry model $(f(D)=1 / \mathrm{RH}$, where RH is relative humidity) (Ball et al., 1987), the Leuning model $\left(f(D)=1 /\left(1+D / D_{0}\right)\right.$ (Leuning, 1995), and the model of Medlyn et al. (2011), who showed that $f(D)=$ $1 / \sqrt{D}$ follows from the assumption that $g_{\mathrm{s}}$ varies to maintain $\delta A / \delta E$ constant (cf. Cowan and Farquhar, 1977). The fourth option, which is used in the simulations shown in this paper, is a modified form of the Tuzet et al. (2003) model. This model takes into account the observation that the response of stomatal conductance to $D$ and soil water deficit is controlled by the leaf water potential $\left(\Psi_{\mathrm{L}}\right)$ (Comstock and Mencuccini, 1998). Because $\Psi_{\mathrm{L}}$ depends on the soil water potential $\left(\Psi_{S}\right)$ as well as the transpiration rate (which depends on $D), \Psi_{\mathrm{L}}$ summarizes the effect of both $D$ and $\Psi_{S}$ on $g_{\mathrm{s}}$ (Franks, 2004). Tuzet et al. (2003) use a flexible $\Psi_{\mathrm{L}}$ modifier (in place of the $f(D)$ function in Eq. 2),

$f_{\Psi_{\mathrm{L}}}=\frac{1+\exp \left[s_{f} \Psi_{f}\right]}{1+\exp \left[s_{f}\left(\Psi_{f}-\Psi_{\mathrm{L}}\right)\right]}$

where $s_{f}$ and $\Psi_{f}$ are parameters; $\Psi_{f}$ is a reference water potential, and $s_{f}$ is the "steepness" of the response of $f_{\Psi \mathrm{L}}$ to $\Psi_{\mathrm{L}}$. We assume a steady-state in water flow from the soil to the leaf, so that $\Psi_{\mathrm{L}}$ at the gridpoint can be calculated from Ohm's analogy to water transport,

$E_{\mathrm{L}}=k_{\mathrm{L}}\left(\Psi_{\mathrm{S}}-\Psi_{\mathrm{L}}\right)$

where $E_{\mathrm{L}}$ is the leaf transpiration rate $\left(\mathrm{mmol} \mathrm{m}^{-2} \mathrm{~s}^{-1}\right)$, itself dependent on $D$ (and boundary layer effects, see 
Sect. "Calculation of leaf temperature and leaf water potential"), and $k_{\mathrm{L}}$ the leaf-specific hydraulic conductance of the soil-to-leaf pathway (see Sect. "Hydraulics of the soil-to-leaf pathway").

Finally, the coupled model of $g_{\mathrm{s}}$ and $A$ can be solved by using the basic diffusion equation,

$A_{\mathrm{n}}=g_{\mathrm{C}}\left(C_{\mathrm{s}}-C_{\mathrm{i}}\right)$

where $g_{\mathrm{C}}$ is stomatal conductance to $\mathrm{CO}_{2}\left(=g_{\mathrm{s}} / 1.6\right)$. The solution of the system of equations (Eqs. 1, 2 and 5) can be written as a quadratic equation, which yields the $C_{\mathrm{i}}$ (see Wang and Leuning, 1998). We solve the Tuzet model (combination of Eqs. 2-5) numerically, by finding the $\Psi_{\mathrm{L}}$ that is the solution both to Eqs. (3) and (4). This way, a unique $\Psi_{\mathrm{L}}$ is calculated for each grid point in the crown. Variation between trees arises due to shading effects, and $k_{\mathrm{L}}$ is allowed to vary from tree to tree (as specified by the user). Also, $k_{\mathrm{L}}$ is either assumed to be constant within the crown, or to follow a function of height above the ground as specified by the user.

It should be noted that Tuzet et al. (2003) used $C_{\mathrm{i}}$ instead of $C_{\mathrm{a}}$ in their model, but we use $C_{\mathrm{a}}$ to be consistent with Medlyn et al. (2011), and to allow for much more straightforward numerical model solution. The argument by Tuzet et al. (2003) to use $C_{\mathrm{i}}$ instead of $C_{\mathrm{a}}$ is that stomata appear to respond to $C_{\mathrm{i}}$, not $C_{\mathrm{a}}$ (Mott, 1988). However, we note that $C_{\mathrm{i}}$ is still implicit in Eq. (2), because $A_{\mathrm{n}}$ depends on $C_{\mathrm{i}}$ through Eq. (1), and $A_{\mathrm{n}}$ and $g_{\mathrm{s}}$ are coupled by $C_{\mathrm{i}}$ through Eq. (5).

\section{Calculation of leaf temperature and leaf water potential}

For the soil water balance, we use the Penman-Monteith equation applied at the canopy level (see Sect. "Total canopy transpiration"), to arrive at consistent calculations for stand energy balance, and boundary layer calculations for soil surface and canopy. At the leaf-level for each grid-point in the crown, transpiration $\left(E_{\mathrm{L}}\right)$ is calculated to yield $\Psi_{\mathrm{L}}$ that is the solution to the Tuzet model of stomatal conductance (Eqs. 2 and 3), and to provide estimates of leaf temperature throughout the crown. For each grid point, $E_{\mathrm{L}}$ is calculated with the Penman-Monteith equation (Eq. 6), which takes into account boundary layer effects on the exchange of water vapour between leaves and the surrounding air. An iterative scheme is used that finds the leaf temperature that closes the energy balance of the leaf (following Wang and Leuning, 1998). Full details are provided in Medlyn et al. (2007).

\section{Total canopy transpiration}

In MAESPA, the soil water balance is calculated using the spatially-averaged transpiration rate by the stand. This spatial average is calculated for a sample of trees specified by the user (the "target trees"), to limit computing time. An example of a selection of target trees is given in Fig. 3. We have chosen not to simulate spatial variation in soil water content based

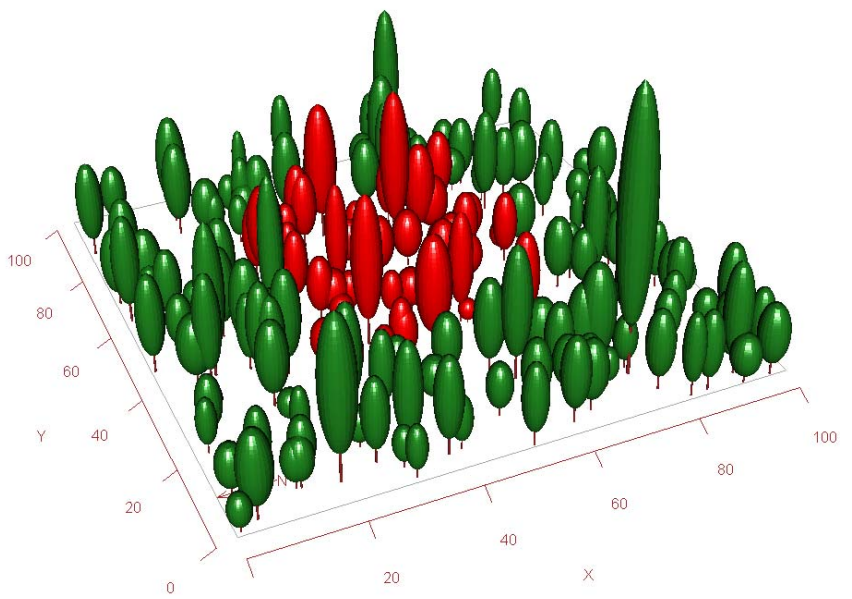

Fig. 3. Example of a stand of trees as represented in the MAESPA model. Water use and carbon uptake are calculated for a sample of target trees, here shown in red, and then added to give the totals for the stand. It is recommended to select a set of target trees that are representative of the stand, and to account for edge effects.

on water uptake of the single trees in a stand, because such a model would be very difficult to parameterize and test.

This approach requires that we scale up estimates of transpiration to the stand level, and estimate total global (shortwave + longwave) radiation reaching the forest floor (for the soil heat balance calculations, see Sect. 2.1.4). Absorbed radiation (photosynthetically active radiation (PAR), nearinfrared radiation (NIR) and thermal) is summed for each tree, and corrected for the difference in leaf area per tree for the sample trees, and that for the entire stand. Using the stand density, estimates of global radiation $\left(\mathrm{W} \mathrm{m}^{-2}\right)$ incident on the soil surface are obtained. Next, the average whole-tree conductance (mol tree ${ }^{-1} \mathrm{~s}^{-1}$ ) is calculated across the sample trees (weighed by their total leaf areas), and once again corrected for the difference in tree leaf area between sample trees, and the average tree in the entire stand. Stand transpiration is re-calculated using this average canopy conductance, and the intercepted radiation per tree, using the PenmanMonteith equation,

$\lambda E_{\mathrm{T}}=\frac{s R_{\mathrm{n}}+D g_{\mathrm{B}} c_{\mathrm{p}} M_{\mathrm{a}}}{s+\gamma g_{\mathrm{B}} / g_{\mathrm{V}}}$

where $\lambda$ the latent heat of water vapour $\left(\mathrm{J} \mathrm{mol}^{-1}\right), E_{\mathrm{T}}$ is canopy transpiration (mol m${ }^{-2}$ (ground) $\mathrm{s}^{-1}$ ), $s$ the slope of the relation between saturation vapour pressure and temperature $\left(\mathrm{Pa} \mathrm{K}^{-1}\right), R_{\mathrm{n}}$ net radiation $\left(\mathrm{W} \mathrm{m}^{-2}\right), g_{\mathrm{B}}$ the boundary layer conductance, and $g_{\mathrm{V}}$ the total conductance to water vapour. The boundary layer conductance $\left(g_{\mathrm{B}}, \mathrm{mol} \mathrm{m}^{-2} \mathrm{~s}^{-1}\right)$ for the canopy is calculated following Jones (1992),

$g_{\mathrm{B}}=\frac{c \times k_{\mathrm{V}}^{2} \times u_{z}}{\left[\log \left(\left(z_{\mathrm{H}}-z_{\mathrm{D}}\right) / z_{0}\right)\right]^{2}}$ 
where $k_{\mathrm{V}}$ von Karman's constant, $u_{z}$ the wind speed measured at a height of $z_{\mathrm{H}}$, and $c$ converts to molar units. The parameters $z_{\mathrm{D}}$ and $z_{0}$ are related to the extinction of wind speed above and within the canopy: $z_{0}$ is the "roughness length" related to the roughness of the canopy surface, and $z_{\mathrm{D}}$ is a reference height. Both these parameters may be estimated from canopy height (Jones, 1992, p. 68), or from more detailed methods that account for stand structure (Schaudt and Dickinson, 2000).

The total conductance to water vapour is,

$g_{\mathrm{V}}=1 /\left(\frac{1}{g_{\mathrm{C}}}+\frac{1}{g_{\mathrm{B}}}\right)$

where $g_{\mathrm{C}}$ the canopy conductance $\left(\mathrm{mol} \mathrm{m}^{-2} \mathrm{~s}^{-1}\right)$, which is estimated by averaging total conductance ( $\mathrm{mol}_{\text {tree }} \mathrm{e}^{-1} \mathrm{~s}^{-1}$ ) across the sample trees weighed by their total leaf areas, and multiplying by stand density $\left(\mathrm{m}^{-2}\right)$.

\subsubsection{Water balance}

\section{Overview}

The soil water balance is calculated for a horizontally homogenous soil compartment, separated vertically in a number of layers (typically ca. 10, specified by the user). The advantage of a multi-layer soil model is that the root density distribution can be specified, as well as vertical variation in soil texture. Furthermore, experiments have shown that plant water potential tends to equilibrate with the wettest zones in the soil, not the average soil water potential (Schmidhalter, 1997). Only a multi-layer soil model can reproduce this observation.

In MAESPA, the soil water storage in each of the horizontally homogenous layers $\left(s_{i}, \mathrm{~mm}\right)$ is calculated from infiltration $\left(I_{i}\right)$, drainage $\left(D_{i}\right)$, root water uptake $\left(E_{i}\right)$ and soil evaporation $\left(E_{\mathrm{s}, i}\right)$ (Eq. 9), at the same time-step as the aboveground processes (typically, half-hourly). Soil evaporation draws water only from the top layer. Drainage out of the lowest root layer is defined as deep drainage.

$$
\begin{aligned}
& \frac{\mathrm{d} s_{i}}{\mathrm{~d} t}=I_{i}-E_{i}-D_{i} \text { for } i>1, \text { and } \\
& \frac{\mathrm{d} s_{i}}{\mathrm{~d} t}=I_{i}-E_{i}-D_{i}-E_{\mathrm{s}, i} \text { for layer } 1 .
\end{aligned}
$$

\section{Infiltration}

The rain that reaches the soil surface is assumed to infiltrate into more than just the top layer. This is accounting for rapid soil water flow through macropores (accounting for increases in soil water content at depth after heavy rainfall that cannot be accounted for by matric drainage rates). We use a simple exponential function (taken from the BROOK90 model, (Federer et al., 2003) (Eq. 10).

$$
\begin{aligned}
& \text { For } i=1, I_{i}=P_{u} \times\left(z_{i} / Z\right)^{\phi} \\
& \text { For } i>1, I_{i}=P_{u} \times\left(\left(\left(\sum_{1}^{i} z_{i}\right) / Z\right)^{\phi}-\left(\left(\sum_{1}^{i-1} z_{i}\right) / Z\right)^{\phi}\right)
\end{aligned}
$$

where $\phi$ is an infiltration parameter (0-1), $z_{i}$ the depth to the bottom of layer $i(\mathrm{~m})$, and $Z$ the total soil depth (m). If $\phi=$ 0 , all infiltration occurs in the top soil layer (no macropore flow). If $\phi=1$, all layers receive equal infiltration.

\section{Root water uptake}

Total water uptake is distributed among soil layers according to the fine root density and soil water potential in those layers. The fraction of roots in each layer can be specified manually, or assumed to follow Eq. (11), which is useful because Jackson et al. (1996) have summarized a large database on root distributions with this equation.

$F_{\mathrm{R}}=\left(1-\beta^{100 \cdot z_{i}}\right) /\left(1-\beta^{100 \cdot Z}\right)$

where $F_{\mathrm{R}}$ is the cumulative fraction of fine roots to depth $z$ $(\mathrm{m})$, and $\beta$ is a parameter that specifies the shape of the distribution (see Jackson et al., 1996). Soil depth is multiplied by 100 , to be consistent with Jackson et al. (1996) who specified $z$ in $\mathrm{cm}$. We have modified the original equation so that the total fine root length (an input parameter) is reached at the maximum depth of the rooting profile.

The root system can be viewed as a combination of resistances that are coupled in parallel, consisting of a soil-toroot surface resistance $\left(R_{\mathrm{sr}}\right)$ and a resistance to water uptake by the root itself (the radial resistance, $R_{\text {rad }}$ ). Because water transport is largely passive, following gradients in water potential from soil to roots, the relative water uptake by different layers in the soil follows from the partitioning of the resistances to water uptake in these layers. Generally, water uptake in a soil layer $\left(E_{i}\right)$ is,

$E_{i}=\left(\Psi_{\mathrm{S}, i}-\Psi_{\mathrm{R}, i}\right) /\left(R_{\mathrm{sr}, i}+R_{\mathrm{rad}, i}+R_{\mathrm{lg}, i}\right)$

where $\Psi_{\mathrm{S}, i}$ is the soil water potential in layer $i, \Psi_{\mathrm{R}, i}$ is the root xylem water potential, $R_{\text {sr }}$ the soil-to root resistance, $R_{\lg i}$ the longitudinal resistance to water flow, and $R_{\text {rad }}$ the radial resistance to water uptake (across the root epidermis to the xylem). This is a very difficult equation to solve simultaneously for multiple soil layers, because $\Psi_{\mathrm{R}, i}, R_{\mathrm{rad}}$ and $R_{\mathrm{lg}}$ are typically unknown, and could vary with depth of the layer (especially $R_{\mathrm{lg}, i}$, as the path length through the root becomes longer). To solve Eq. 12, we follow the assumptions by (Taylor and Keppler, 1975) who showed in an elegant experiment that (1) $R_{\mathrm{lg}}$ is very small compared to $R_{\mathrm{rad}}$, so that $\Psi_{\mathrm{R}, i}$ can be taken as a constant, and (2) $R_{\mathrm{sr}}$ is small compared to $R_{\mathrm{rad}}$, except in very dry soil. Because $R_{\text {rad }}$ is inversely proportional 
to the total fine root length in a soil layer, it follows that,

$E_{i} \propto L_{\mathrm{V}, i}\left(\Psi_{\mathrm{S}, i}-\overline{\Psi_{\mathrm{R}}}\right)$

where $\overline{\Psi_{\mathrm{R}}}$ is a mean root water potential, and $L_{\mathrm{v}, i}$ the fine root density $\left(\mathrm{m} \mathrm{m}^{-3}\right)$ in layer $i$. The constant of proportionality may be found from the fact that $\sum E_{i}=E_{\mathrm{T}}$, where $E_{\mathrm{T}}$ is the total water uptake. Note that we do include $R_{\mathrm{sr}}$ in the calculations of the overall resistance of the soil-to-leaf pathway (see Sect. "Hydraulics of the soil-to-leaf pathway"), but omit it here to simplify the fractional uptake of water from different soil layers. The mean root water potential is taken as the minimum value allowed for roots $\left(\Psi_{\mathrm{Rmin}}\right)$, an input parameter; so that no uptake is possible in soil layers where the soil water potential is lower than $\Psi_{\mathrm{Rmin}}$ ). When $\Psi_{\mathrm{R}}>\Psi_{\mathrm{S}}$, it is assumed that water does not flow from roots back into the soil, that is, we do not consider hydraulic redistribution in our model (see Domec et al., 2012).

\section{Soil evaporation}

The evaporation of water from the soil surface is estimated with a physical-based model developed by Choudhury and Monteith (1988), and modified by Williams et al. (2001a). Soil evaporation draws water only from the top layer, and assumes that water has to travel through a thin dry layer at the soil surface.

The rate of evaporation $(\mathrm{mm})$ is determined from the difference between water vapour pressure in the soil pore space and the air above, and a conductance to vapour transfer (Eq. 14),

$$
E_{\mathrm{s}}=G_{\mathrm{s}, \mathrm{t}} k_{1}\left(e_{\mathrm{s}}-e_{\mathrm{a}}\right)
$$

where $G_{\mathrm{s}, \mathrm{t}}$ is the total conductance from the soil air space to the air above the boundary layer $\left(\mathrm{m} \mathrm{s}^{-1}\right), e_{\mathrm{a}}$ the partial water vapour pressure of the air $(\mathrm{kPa})$, and $e_{\mathrm{s}}$ that of the soil pore space $(\mathrm{kPa})$. The term $k_{1}$ converts from pressure units to volumetric units. $G_{\mathrm{s}, \mathrm{t}}$ is the total conductance, including the path through the soil $\left(G_{\mathrm{ws}}\right)$, and that through the boundary layer just above the soil surface $\left(G_{\mathrm{am}}\right)$. The latter is estimated following Eq. (7) (Sect. "Total canopy transpiration"), with the reference height $z_{\mathrm{D}}$ set to zero. Next, $G_{\mathrm{ws}}$ is estimated from the diffusivity of water vapour, which is soil temperature dependent, and the tortuosity of the soil air pathway, which determines the effective path length for vapour transfer.

$G_{\mathrm{ws}}=D_{\mathrm{eff}}\left(\theta_{1} / L_{\mathrm{d}}\right)$

$D_{\text {eff }}=\omega_{s} \theta_{1} D_{\mathrm{w}}$

where $D_{\text {eff }}$ is the effective diffusivity, $\omega_{s}$ a tortuosity parameter, $\theta_{1}$ the pore fraction of the top soil layer, $L_{\mathrm{d}}$ the thickness of the dry layer at the soil surface, and $D_{\mathrm{w}}$ diffusivity of water vapour (calculated following Jones (1992) accounting for soil temperature). The rationale for Eq. (15) (Choudhury and
Monteith, 1988) is that $G_{\mathrm{ws}}$ is proportional to the air space in the soil, but inversely proportional to the distance water vapour has to travel. This distance is a function of both the thickness of the dry layer $\left(L_{\mathrm{d}}\right)$, and the tortuosity of the dry layer (Eq. 16). $L_{\mathrm{d}}$ depends on the timing of the last rainfall, and the rate of soil evaporation, but is not affected by plant water uptake. Following Williams et al. (2001b), MAESPA keeps track of multiple dry layers to account for complex dynamics with short intermittent storms. A minimum value $\left(L_{\mathrm{d}, \mathrm{min}}\right)$ is specified as a parameter to prevent very high rates of soil evaporation in wet soil.

The partial pressure of water vapour in the soil pore space is calculated from,

$e_{\mathrm{S}}=e_{\mathrm{sat}} \times \exp \left\{\Psi_{\mathrm{s}, 1} V_{\mathrm{w}} /\left(R T_{\mathrm{s}}\right)\right\}$

where $e_{\text {sat }}$ is the saturated vapour pressure (calculated from temperature following Jones 1992), $\Psi_{\mathrm{s}, 1}$ the soil water potential in the surface layer, $V_{\mathrm{w}}$ the partial molal volume of water $\left(\mathrm{m}^{3} \mathrm{~mol}^{-1}\right), R$ the gas constant, and $T_{\mathrm{s}}$ the soil surface temperature $(\mathrm{K})$.

\section{Canopy interception}

The Rutter et al. (1975) model of canopy rainfall interception is used. Rain has two possible fates: (1) it falls through the canopy without being intercepted or (2) it gets intercepted by the canopy, where it adds to a pool of canopy water, that slowly drains. If the maximum canopy pool is reached, all additional rainfall in that time-step drains immediately. Water also evaporates from the wet canopy, determined by the Penman-Monteith equation (see Sect. "Total canopy transpiration"), using infinite canopy conductance (because free water is available), but with VPD set to a very low value.

The change in canopy water storage $\left(W_{\text {can }}\right)$ is given by,

$\frac{\mathrm{d} W_{\mathrm{can}}}{\mathrm{d} t}=\left(1-r_{1}\right) P-E_{\mathrm{w}}-e^{r_{2}+r_{3} W_{\mathrm{can}}}$

where $E_{\mathrm{w}}$ the wet evaporation rate $\left(\mathrm{mm} \mathrm{t}^{-1}\right), r_{1}$ the free throughfall fraction (0-1), and $r_{2}$ and $r_{3}$ are canopy drainage parameters. This differential equation is integrated with a Runge-Kutta method to obtain canopy throughfall, canopy storage, and wet evaporation rates.

\section{Drainage}

The vertical drainage of soil water is estimated directly from the soil hydraulic conductivity, which itself is a function of the soil water content. After adding the infiltration of rainfall to the soil water content for each layer, the water balance for each soil layer becomes,

$\frac{\mathrm{d} W_{\mathrm{i}}}{\mathrm{d} t}=D_{i-1}\left(\theta_{i-1}\right)-D_{i}\left(\theta_{\mathrm{i}}\right)$

where $D_{i}$ is the drainage from layer $i$. Because water is assumed to not travel upwards in the soil, this equation can be 
solved for one layer at a time, starting at the top and moving downward. Drainage is simply equal to the soil hydraulic conductivity $\left(\mathrm{m} \mathrm{s}^{-1}\right)$ in that layer, which is calculated from $\theta_{\mathrm{i}}$. The system of equations is solved with a Runge-Kutta integrator (following the SPA model, Williams et al., 2001a, b).

\section{Hydraulics of the soil-to-leaf pathway}

We use the simple set of equations developed by (Campbell, 1974) for the dependence of soil water potential and the hydraulic conductivity on the soil water content. Soil water potential $\left(\Psi_{\mathrm{S}}, \mathrm{MPa}\right)$ is given by Eq. (20),

$\Psi_{\mathrm{s}}=\Psi_{e}\left(\frac{\theta}{\theta_{\mathrm{sat}}}\right)^{-b}$

where $\theta$ the soil volumetric water content $\left(\mathrm{m}^{3} \mathrm{~m}^{-3}\right), \theta_{\text {sat }}$ the soil porosity, and $\Psi_{e}$ and $b$ are soil texture dependent parameters (see Cosby et al., 1984). Each of these parameters can vary by soil layer ( $i$ subscripts are omitted for clarity). The soil hydraulic conductivity is estimated from Eq. (21),

$K_{S}\left(\Psi_{\mathrm{s}}\right)=K_{\mathrm{sat}}\left(\frac{\Psi_{e}}{\Psi_{\mathrm{s}}}\right)^{2+3 / b}$

where $K_{s}$ the conductivity $\left(\mathrm{mol} \mathrm{m}^{-1} \mathrm{~s}^{-1} \mathrm{MPa}^{-1}\right), \Psi_{e}$ and $b$ are the same parameters as in Eq. (20) (using the fact that conductivity and water potential are physically related), and $K_{\text {sat }}$ is the saturated hydraulic conductivity $\left(\mathrm{mol} \mathrm{m}^{-1} \mathrm{~s}^{-1} \mathrm{MPa}^{-1}\right)$.

The soil-to-root resistance (MPa s $\mathrm{m}^{2}$ (ground) $\mathrm{mol}^{-1}$ ) is estimated with the single root model of Gardner (1960) (see Williams et al., 2001a and Duursma et al., 2008 for more details). This model estimates the effective path length for water transport through the soil matrix to the root surface from the fine root density. The equation is,

$R_{\mathrm{sr}, i}=\frac{\log \left(\frac{r_{\mathrm{s}}}{r_{\mathrm{r}}}\right)}{2 \pi L_{\mathrm{V}} H_{\mathrm{S}} K_{s}}$

where $r_{\mathrm{r}}$ the mean root radius (m), $L_{v}$ the total fine root density $\left(\mathrm{m} \mathrm{m}^{-3}\right)$ in the soil layer, $H_{\mathrm{S}}$ the height of the soil layer, and $r_{\mathrm{S}}$ the mean distance between roots $\left(1 / \sqrt{\pi L_{\mathrm{V}}}\right)$. The total resistance for all soil layers combined $\left(R_{\mathrm{sr}, \mathrm{t}}\right)$ is estimated by assuming that the resistances are coupled in parallel. The total leaf-specific hydraulic conductance $\left(k_{\mathrm{L}}\right.$, mmol m${ }^{-2}$ (leaf) $\mathrm{s}^{-1} \mathrm{MPa}^{-1}$ ) from soil to leaf can now be found as,

$k_{\mathrm{L}}=1 /\left(\frac{1}{k_{\mathrm{P}}}+R_{\mathrm{sr}, \mathrm{t}} \times L_{\mathrm{T}}\right)$

where $L_{\mathrm{T}}$ total canopy leaf area index ( $\mathrm{m}^{2}$ (leaf) $\mathrm{m}^{-2}$ (ground)), and $k_{\mathrm{P}}$ the plant component of the leaf-specific hydraulic conductance $\left(\mathrm{mmol} \mathrm{m}^{-2} \mathrm{~s}^{-1} \mathrm{MPa}^{-1}\right)$, which is typically estimated from measurements of $E_{\mathrm{L}}$ and
$\Psi_{\mathrm{L}}$ under well-watered conditions (see, e.g. Delzon et al., 2004). It is assumed that $k_{\mathrm{P}}$ includes the root components of the plant pathway (defined in Eq. 12 by the resistances $R_{\mathrm{rad}}$ and $R_{\mathrm{lg}}$ ), and that these components do not change with the plant water potential.

Following Williams et al. (2001a), we calculate a weighted soil water potential for use in the calculation of $\Psi_{\mathrm{L}}$ and stomatal conductance. The $\Psi_{s}$ in each layers is weighed by the maximum water transport possible in that layer, depending on $R_{\mathrm{sr}}$ in that layer and a minimum root water potential $\left(\Psi_{\mathrm{R}, \min }\right)$,

$\Psi_{\mathrm{S}}=\frac{\sum_{i=1}^{N} \Psi_{\mathrm{S}, i} \times E_{\mathrm{max}, i}}{\sum_{i=1}^{N} E_{\mathrm{max}, i}}$ where $E_{\mathrm{max}, i}=\left(\Psi_{\mathrm{S}, i}-\Psi_{\mathrm{R}, \min }\right) / R_{\mathrm{sr}, i}$.

\subsubsection{Soil heat balance}

\section{Overview}

The components of the soil surface heat balance are calculated to arrive at the soil surface temperature, and the vertical gradient of soil temperature. The soil surface temperature affects only the soil evaporation (see Sect. "Soil evaporation"). If soil evaporation is not of interest, or can be assumed negligible, the soil heat balance need not be calculated (thereby simplifying the parameterization).

\section{Soil surface temperature}

The soil energy balance is the sum of four heat fluxes: net radiation $\left(Q_{\mathrm{n}}\right)$, soil surface evaporation (latent heat flux) $\left(Q_{e}\right)$, soil heat transport (to deeper soil layers) $\left(Q_{c}\right)$ and sensible heat flux $\left(Q_{\mathrm{h}}\right)$. Due to conservation of energy, these fluxes sum to zero at any time:

$Q_{\mathrm{n}}+Q_{e}+Q_{c}+Q_{h}=0$.

All the components in Eq. (25) depend on the soil surface temperature $\left(T_{\mathrm{s}, 1}\right)$. The MAESPA model finds the soil surface temperature that provides closure in the soil energy balance.

Net radiation on the soil surface $\left(Q_{\mathrm{n}}\right)$ is global radiation (solar + downward thermal) minus long-wave radiation $\left(Q_{\mathrm{L}}\right)$ emitted by the soil surface. The latter depends on the soil surface temperature (Eq. 26).

$Q_{\mathrm{L}}=\varepsilon \sigma T_{\mathrm{s}}^{4}$

where $\varepsilon$ is the emissivity (assumed to equal 0.95 ), $\sigma$ the Stefan-Boltzmann constant $\left(\mathrm{W} \mathrm{m}^{-2} \mathrm{~K}^{-4}\right)$ and $T_{\mathrm{S}}$ is in $\mathrm{K}$. Global down-welling radiation is the sum of short-wave radiation (i.e. solar radiation minus that intercepted by the canopy), and long-wave radiation emitted by the canopy.

The soil latent heat flux $\left(Q_{e}\right)$ is calculated from soil evaporation (see Sect. "Soil evaporation"), and the latent heat of evaporation (a function of temperature; Jones, 1992). 
Soil heat transport $\left(Q_{c}\right)$ follows from the difference in soil temperature between the first and second layer,

$Q_{c}=K_{\mathrm{th}}\left(T_{\mathrm{s}, 2}-T_{\mathrm{s}, 1}\right) / \Delta z_{1,2}$

where $K_{\text {th }}$ is the the soil thermal conductivity $\left(\mathrm{W} \mathrm{m}^{-1} \mathrm{~K}^{-1}\right.$, see Sect. "Soil surface temperature"), and $\Delta z_{1,2}$ the depth difference between the second and first layer $(\mathrm{m})$.

Sensible heat flux $\left(Q_{\mathrm{h}}\right)$ is calculated from the difference between air temperature and soil surface temperature, and the total conductance to heat (Eq. 28)

$Q_{\mathrm{h}}=c_{p} \rho G_{\mathrm{a}, \mathrm{m}}\left(T_{\mathrm{s}, 1}-T_{\mathrm{air}}\right)$

where $c_{p}$ the heat capacity of air $\left(\mathrm{J} \mathrm{kg}^{-1} \mathrm{~K}^{-1}\right.$, a constant), $\rho$ the (temperature-dependent) density of air $\left(\mathrm{kg} \mathrm{m}^{-3}\right), G_{\mathrm{a}, \mathrm{m}}$ the boundary layer conductance to heat transfer (assumed to be equal to that of water vapour transfer, see Sect. "Soil evaporation"), and $T_{\mathrm{s}, 1}-T_{\text {air }}$ the temperature gradient between soil surface and the air.

\section{Soil temperature profile}

The transport of heat down the soil temperature gradient is calculated following the SPA model (Williams et al., 2001b). The Fourier heat transport equation is solved using the Crank-Nichols scheme (Press et al., 1990) resulting in a soil temperature profile and corresponding heat fluxes between soil layers. Inputs for this routine are the soil thermal conductivity (by layer), and soil heat capacity.

We used an empirical model developed by Lu et al. (2007) to estimate the soil thermal conductivity (in $\mathrm{W} \mathrm{m}^{-1} \mathrm{~K}^{-1}$ ) from soil porosity, water content, temperature and organic matter content. Their model takes slightly different parameter values for fine and coarse textured soils; we used the soil texture parameter ( $b$ in Eq. 20) to determine which parameter set to use (based on their Table 1 , we used $b=5.3$ below which soils are considered "coarse textured"). With this method, it is straightforward to set the top layer of the soil as a "litter layer" that effectively insulates the soil through a very low thermal conductivity.

The heat capacity of the soil is determined by separating the soil into solid (quartz) and water fractions, and finding the weighted average of their heat capacities (cf. de Vries, 1963; see also Ogée et al., 2001), and assuming that the soil air fraction has negligible heat capacity.

\subsection{Parameterization}

In MAESPA, the water balance is calculated for a horizontally homogenous soil, but the canopy consists of a collection of single trees. Canopy transpiration is estimated based on transpiration by the "sample trees", and it is therefore vital that these sample trees represent the canopy in terms of water use. It is recommended that MAESPA is run for a large number of sample trees, for example in an arrangement shown in Fig. 3. For all trees in the stand, estimates of leaf area, crown shape, crown width, crown length and height to crown base are needed. Stands may also consist of just one tree, in which case the product of plot size and rooting depth can be interpreted as the soil volume, or pot volume, available to the tree.

Environmental drivers need to be specified on a (half-)hourly time-step, and include air temperature, solar radiation, precipitation, relative humidity and optionally wind speed and $\mathrm{CO}_{2}$ concentration. For the water balance, crucial parameters are total rooting depth and the soil water retention curve. The latter can be estimated from soil texture, and equations summarized by e.g. Saxton and Rawls (2006) and Cosby et al. (1984). A brief summary of the list of parameters needed to run the water balance component of MAESPA is given in Table B1.

\subsection{Implementation and batch utility}

MAESPA is written in Fortran, with simple text-based input and output files. An R (R Development Core Team, 2011) package is available, Maeswrap, which aides sensitivity analysis and other computer-intensive simulation studies. This also includes a utility to graph the stand in 3-D (Fig. 3 was produced with the Maeswrap package). The compiled model and the source code are available on the MAESTRA website (see Sect. 2.1).

\subsection{Application of MAESPA: a case study on the inter- action between $C_{\mathrm{a}}$ and drought}

In the following, we present three brief case studies that illustrate the application of the MAESPA model to studying complex interactions between environmental drivers and plant parameters. All case studies analyse the interaction between atmospheric $\mathrm{CO}_{2}$ concentration $\left(C_{\mathrm{a}}\right)$ and drought.

\subsubsection{Dry-down simulations}

We simulated the response of several plant variables to a drydown in order to establish a clear picture of the baseline expectation of the interaction between $C_{\mathrm{a}}$ and drought, that is, the interaction when $C_{\mathrm{a}}$-related feedbacks and acclimation are ignored. We used a hypothetical stand with total leaf area index of $3.8 \mathrm{~m}^{2} \mathrm{~m}^{-2}$, with a default leaf physiology parameter set (see Table 2 for parameters and their values), and the Tuzet model of stomatal conductance (Eqs. 2 and 3). Ambient $C_{\mathrm{a}}$ was set to $380 \mathrm{ppm}$, and elevated $C_{\mathrm{a}}$ was chosen as $620 \mathrm{ppm}$ (Barton et al., 2010). Weather data was generated for a typical sunny summer day, using the Bristow and Campbell algorithm (Bristow and Campbell, 1984), and was the same for each day during the dry down, as was the solar angle (although it did change during the day). 
Table 2. Important parameters for the simulation of a dry-down on daily whole-plant gas exchange and plant water relations. The soil type was a loamy sand (parameters from Cosby et al., 1984). Halfhourly weather data were estimated from daily $T_{\text {air }}$ amplitude.

\begin{tabular}{ll}
\hline Parameter & Value \\
\hline Number of soil layers & 10 \\
Root distribution $(\beta)$ & 0.98 \\
$B$ & 4.3 \\
$\Psi_{\mathrm{e}}$ & $-0.35 \mathrm{kPa}^{-1} \mathrm{~s}^{-1} \mathrm{MPa}^{-1}$ \\
$K_{\mathrm{sat}}$ & $200 \mathrm{~mol} \mathrm{~m}^{-2} \mathrm{~s}^{-1}$ \\
$g_{0}$ & $0.01 \mathrm{~mol} \mathrm{~m}^{-1}$ \\
$g_{1}$ (Tuzet model) & 4.5 \\
$s_{f}$ & $3.2 \mathrm{MPa}^{-1}$ \\
$\Psi_{f}$ & $-1.9 \mathrm{MPa}^{-2} \mathrm{~mol} \mathrm{~m}^{-1} \mathrm{MPa}^{-1}$ \\
$k_{\mathrm{P}}$ & $2 \mathrm{mmol}^{-1}$ \\
$J_{\text {max }}$ & $150 \mu \mathrm{mol} \mathrm{m}^{-2} \mathrm{~s}^{-1}$ \\
$V_{\mathrm{cmax}}$ & $90 \mu \mathrm{mol} \mathrm{m}^{-2} \mathrm{~s}^{-1}$ \\
Tree leaf area & $35 \mathrm{~m}^{2}$ \\
Stand density & $1100 \mathrm{trees} \mathrm{ha}^{-1}$ \\
Daily max. $D$ & $3.0 \mathrm{kPa}^{\circ}$ \\
Daily $T_{\max }-T_{\min }$ & $10-30{ }^{\circ} \mathrm{C}$ \\
$C_{\mathrm{a}}$ & $380 \mathrm{ppm}$ \\
Wind speed & $0.5 \mathrm{~m} \mathrm{~s}^{-1}$ \\
\hline
\end{tabular}

\subsubsection{Effect of acclimation of leaf parameters on $C_{\mathrm{a}} \times$} drought interaction in water use and $\mathrm{CO}_{2}$ uptake

Acclimation of leaf physiology to long-term growth at e $C_{\mathrm{a}}$ is one possible explanation for why many real-world experiments deviate from baseline expectations of $C_{\mathrm{a}} \times$ drought interactions. We test the impact of acclimation of two leaf physiology parameters, $k_{\mathrm{L}}$ and $\Psi_{f}$. A number of studies have found decreases in the leaf-specific hydraulic conductance $\left(k_{\mathrm{L}}\right)$ in plants grown in e $C_{\mathrm{a}}$ (Atkinson and Taylor, 1996; Eamus et al., 1995; Eguchi et al., 2008; Heath et al., 1997), with reductions in a wide range of $10-100 \%$.

Berryman et al. (1994) found a higher sensitivity of $g_{\mathrm{s}}$ to decreasing water content of excised leaves in Maranthes corymbosa, which can be interpreted as a less negative $\Psi_{f}$ in the Tuzet model (Eq. 3). This observation is also consistent with a higher sensitivity to abscisic acid (ABA) in $C_{\mathrm{a}}$ found in a number of species (Dubbe et al., 1978; McAdam et al., 2011), and the fact that ABA concentrations increase in low $\Psi_{\mathrm{L}}$ (Pierce and Raschke, 1981).

To test the sensitivity of the $C_{\mathrm{a}} \times$ drought interaction to these parameters, we ran two additional dry-down simulations, one with a $50 \%$ reduction in $k_{\mathrm{L}}$ at e $C_{\mathrm{a}}$, and one with a $0.4 \mathrm{MPa}$ increase in $\Psi_{f}$. Both these changes in parameter values are within observed ranges of change with long-term growth at $\mathrm{e} C_{\mathrm{a}}$, but are arbitrary and only chosen to illustrate the effect on the $C_{\mathrm{a}} \times$ drought interaction. All other settings and parameters were as specified in the dry-down simulation (Sect. 2.2.1).

\subsubsection{Drought $\times C_{\mathrm{a}}$ interaction in cherry seedlings}

To illustrate the importance of whole-plant feedbacks in treatment responses, we applied the model to a $C_{\mathrm{a}} \times$ drought experiment. Centritto et al. (1999a, b) describe an experiment where cherry seedlings were grown in ambient $C_{\mathrm{a}}$ concentration $\left(\mathrm{a} C_{\mathrm{a}}\right)(350 \mathrm{ppm})$ and elevated $C_{\mathrm{a}}\left(\mathrm{e} C_{\mathrm{a}} ; 700 \mathrm{ppm}\right)$ treatments in well-watered conditions until half the plants were subjected to a dry-down. The analysis of their results was complicated by the fact that total leaf area of e $C_{\mathrm{a}}$ seedlings was higher than that of $\mathrm{a} C_{\mathrm{a}}$ seedlings, compensating for lower water use per unit leaf area, so that total water use was similar between treatments. We re-analysed their dataset in a model-based framework where we can integrate effects of leaf area, $C_{\mathrm{a}}$, and leaf-level physiology parameters on wholeplant interactions between $C_{\mathrm{a}}$ and drought.

We estimated MAESPA parameters for the cherry seedling based on the published information as much as possible, and found the remaining parameters by fitting to observed data (see below). Details and estimated parameters are presented in Table 3. We constructed a weather dataset based on the latitude of the study and the reported mean air temperature and relative humidity. Daily incident PAR was estimated from air temperature using the Bristow and Campbell algorithm (Bristow and Campbell, 1984). Using the fitted parameter set for a $C_{\mathrm{a}}$ plants, we simulated water use by the e $C_{\mathrm{a}}$ plants, with the only difference that leaf area was increased as observed in the experiment.

\section{Results}

\subsection{The interaction between $C_{\mathrm{a}}$ and drought}

A simulation was carried out to establish baseline behaviour of MAESPA during a dry-down.

At ambient $C_{\mathrm{a}}$, simulated total water use $\left(E_{\mathrm{T}}\right)$ declines earlier and more rapidly than total carbon uptake $\left(A_{\mathrm{T}}\right)$ (Fig. 4a and b), implying that $C_{\mathrm{i}} / C_{\mathrm{a}}$ declines (Fig. 4c) and $A_{\mathrm{T}} / E_{\mathrm{T}}$ increases as the dry-down progresses (Fig. 4d). As the soil water content declines (Fig. 4e), midday leaf water potential $\left(\Psi_{\mathrm{L}}\right)$ decreases steadily, and continues to decrease because of cuticular water loss (Table 2). As $g_{\text {s }}$ decreases during the dry-down, the difference between leaf and air temperature increases (Fig. 4g), and the depth of water uptake gradually shifts to deeper layers (Fig. 4h).

These simulations also summarize our baseline expectations, in the absence of feedbacks or acclimation, for a $C_{\mathrm{a}} \times$ drought interaction. Under e $C_{\mathrm{a}}, E_{\mathrm{L}}$ is initially lower (Fig. 4a), which leads to less negative $\Psi_{\mathrm{L}}$ (Fig. 4f), and a higher soil water content (Fig. 4e). The daily integrated transpiration efficiency $\left(A_{\mathrm{T}} / E_{\mathrm{T}}\right)$ is higher under $\mathrm{e} C_{\mathrm{a}}$, and increases more rapidly under e $C_{\mathrm{a}}$ as compared to a $C_{\mathrm{a}}$ (Fig. $4 \mathrm{~d}$ ). This latter prediction is sensitive to the assumed value for $g_{0}$ (the cuticular conductance), so that a lower $g_{0}$ leads to 

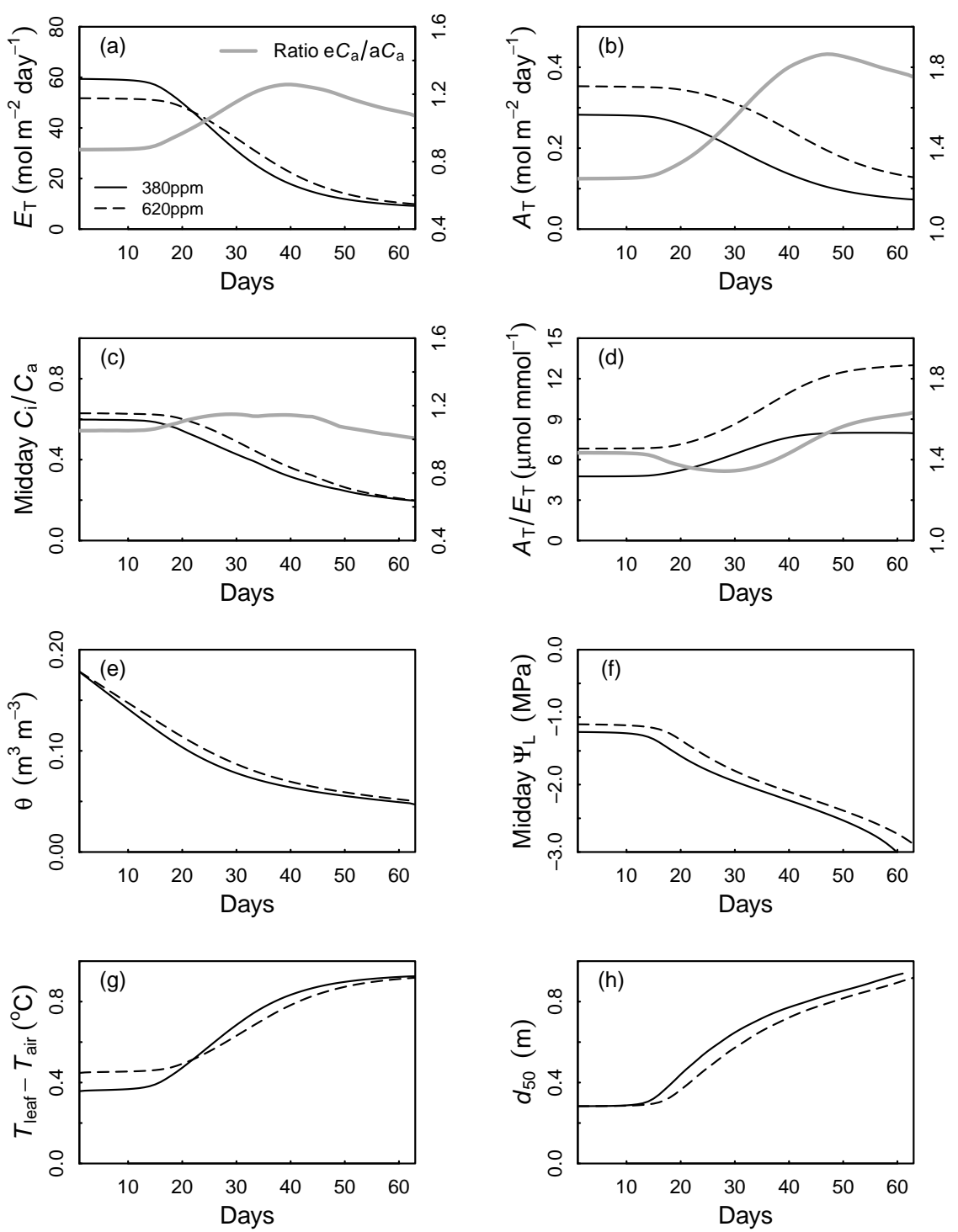

Fig. 4. Simulation of the effect of a dry-down on whole-plant fluxes and water balance under ambient and elevated $C_{\mathrm{a}}$. The simulation was performed for a single tree with $35 \mathrm{~m}^{2}$ leaf area in a stand of identical trees. Fluxes are expressed as averages over the canopy of that single tree. See Table 1 for the parameter set used in the simulation. Shown are the decrease in total water use $\left(E_{\mathrm{T}}\right)$, total daily net photosynthesis $\left(A_{\mathrm{T}}\right)$, midday $C_{\mathrm{i}} / C_{\mathrm{a}}$, the daily integrated transpiration efficiency $\left(A_{\mathrm{T}} / E_{\mathrm{T}}\right)$, volumetric soil water content $(\theta)$, midday leaf water potential for the sunlit leaves $\left(\Psi_{\mathrm{L}}\right)$, the difference between leaf and air temperature $\left(T_{\text {leaf }}-T_{\text {air }}\right)$, and the depth of root water uptake $\left(d_{50}\right.$, the depth above which $50 \%$ of water is taken up). For panels (a)-(d), the ratio of e $C_{\mathrm{a}}$ to a $C_{\mathrm{a}}$ is shown with a grey line. Note the difference in scale for this ratio (right y-axis) for panel (b).

a more pronounced increase in $A_{\mathrm{T}} / E_{\mathrm{T}}$ as the drought progresses (not shown). Both $E_{\mathrm{T}}$ and $A_{\mathrm{T}}$ show a three-phase response when expressed as the ratio e $C_{\mathrm{a}}$ to a $C_{\mathrm{a}}$ (Fig. $4 \mathrm{a}$ and b). At first, when both plants have sufficient water, the ratio is constant. The ratio then increases due to higher soil water content in the $\mathrm{e} C_{\mathrm{a}}$ treatment. When this saved water store is exhausted (by day 40-45), the ratio declines, as both $E_{\mathrm{T}}$ and $A_{\mathrm{T}}$ are increasingly controlled by the cuticular conductance.

MAESPA predicts a strong positive interaction between $C_{\mathrm{a}}$ and drought for two reasons. The first is the "water savings" effect described above: photosynthesis of elevated $C_{\mathrm{a}}$ trees is high for longer due to higher soil moisture. Secondly, even when both treatments are at the same soil water content, photosynthesis is stimulated more by e $C_{\mathrm{a}}$ in dry soil compared to wet soil (Fig. 5a, see also Fig. 4). This response arises because $C_{\mathrm{i}}$ declines as the soil dries out (Fig. 4c), and $A_{\mathrm{n}}$ is more sensitive to $C_{\mathrm{i}}$ at low values of $C_{\mathrm{i}}$, due to the saturating response of $A_{\mathrm{n}}$ to $C_{\mathrm{i}}$. This " $C_{\mathrm{i}}$ effect" is demonstrated in Fig. 5a (solid line). 
Table 3. Important parameter settings for the simulation of the $C_{\mathrm{a}} \times$ drought interaction in cherry.

\begin{tabular}{|c|c|c|}
\hline Parameter & Value & Source \\
\hline Pot volume & $6.6 \mathrm{dm}^{3}$ & \\
\hline Leaf area (start-end) & $0.06-0.08 \mathrm{~m}^{2}\left(\mathrm{a} C_{\mathrm{a}}\right), 0.1-0.115 \mathrm{~m}^{2}\left(\mathrm{e} C_{\mathrm{a}}\right)$ & $\begin{array}{l}\text { Calculated from Centritto et al. (1999a), their Table } 5 \\
\text { and Fig. } 7\end{array}$ \\
\hline$C_{\mathrm{a}}$ & $350\left(\mathrm{a} C_{\mathrm{a}}\right), 700\left(\mathrm{e} C_{\mathrm{a}}\right)$ & \\
\hline$V_{\text {cmax }}$ at $25^{\circ} \mathrm{C}$ & $50 \mu \mathrm{mol} \mathrm{m}^{-2} \mathrm{~s}^{-1}$ & $\begin{array}{l}\text { Estimated by visually fitting Eq. (1) to Fig. } 3 \text { in } \\
\text { Centritto et al. (1999b) }\end{array}$ \\
\hline$J_{\max }$, at $25^{\circ} \mathrm{C}$ & $100 \mu \mathrm{mol} \mathrm{m}{ }^{-2} \mathrm{~s}^{-1}$ & As above \\
\hline$b$ & 4.3 & Loamy sand \\
\hline$\Psi_{\mathrm{e}}$ & $-0.35 \mathrm{kPa}$ & Loamy sand \\
\hline$\theta_{\text {sat }}$ & $0.6 \mathrm{~m}^{3} \mathrm{~m}^{-3}$ & Typical value \\
\hline$\Psi_{f}$ & $-2.3 \mathrm{MPa}$ & Fitted \\
\hline$s_{f}$ & $2.2 \mathrm{MPa}^{-1}$ & Fitted \\
\hline$g_{1}$ (Tuzet model) & 5.5 & Fitted \\
\hline$k_{\mathrm{P}}$ & $1.35 \mathrm{mmol} \mathrm{m}^{-2} \mathrm{~s}^{-1} \mathrm{MPa}^{-1}$ & Fitted \\
\hline$\Psi_{\mathrm{Rmin}}$ & $-3 \mathrm{MPa}$ & Assumed value \\
\hline$\beta$ & 0.99 & Typical value; Jackson et al. (1996) \\
\hline
\end{tabular}
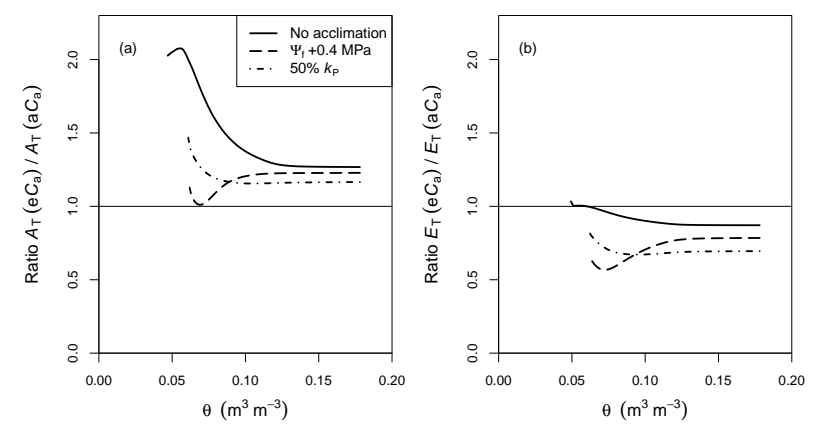

Fig. 5. Illustration of the influence of acclimation on the interaction between $C_{\mathrm{a}}$ and drought. Panel (a), relative $C_{\mathrm{a}}$ effect on total canopy $\mathrm{CO}_{2}$ uptake $\left(A_{\mathrm{T}}\right)$ as a function of soil water content $(\theta)$ during a simulated dry-down. Panel (b) shows total canopy transpiration rate $\left(E_{\mathrm{T}}\right)$ for the same simulations. The solid line shows the interaction when all plant parameters are unchanged due to growth at e $C_{\mathrm{a}}$ ("no acclimation"). Note that in very dry soil, transpiration rates are similar in $C_{\mathrm{a}}$ and $\mathrm{e} C_{\mathrm{a}}$, but the stimulation of $A_{\mathrm{T}}$ due to $C_{\mathrm{a}}$ is much higher than in wet soil (a positive interaction of drought and $\mathrm{e} C_{\mathrm{a}}$ ). These effects are much reduced for a higher sensitivity to $\Psi_{\mathrm{L}}$ in the stomatal conductance model (" $\Psi_{f}+0.4 \mathrm{MPa")}$, which leads to a negative interaction between $C_{\mathrm{a}}$ and drought (the $C_{\mathrm{a}}$ effect is less in dry soil than wet soil, for both $E_{\mathrm{T}}$ and $A_{\mathrm{T}}$ ). A lower plant hydraulic conductance $\left(k_{\mathrm{P}}\right)$ reduces $E_{\mathrm{T}}$ in wet soils, and greatly reduces the positive interaction of $C_{\mathrm{a}}$ and drought that was found without acclimation.
We studied the effect of acclimation of two leaf physiology parameters, the leaf-specific hydraulic conductance $\left(k_{\mathrm{P}}\right)$ and the sensitivity to $\Psi_{\mathrm{L}}\left(\Psi_{f}\right.$, Eq. 3), on the " $C_{\mathrm{i}}$ effect". When $k_{\mathrm{P}}$ is reduced by $50 \%$, the strong positive interaction with soil water content as observed in the baseline simulation is much reduced (Fig. 5a), so that the e $C_{\mathrm{a}}$ stimulation of $A_{\mathrm{T}}$ is only moderately dependent on soil water content. When $\Psi_{f}$ is increased by $0.4 \mathrm{MPa}$, the interaction even reversed, so that $A_{\mathrm{T}}$ decreases with e $C_{\mathrm{a}}$ in very dry soil (Fig. 5a) and $E_{\mathrm{T}}$ is reduced by e $C_{\mathrm{a}}$ in very dry soil (Fig. $5 \mathrm{~b}$ ). This occurs because a higher $\Psi_{f}$ leads to reduced stomatal conductance in e $C_{\mathrm{a}}$ compared to a $C_{\mathrm{a}}$ as the $\Psi_{\mathrm{L}}$ declines in dry soil.

Plant size may change following long-term growth at e $C_{\mathrm{a}}$, which can feed back to drought responses and modify $C_{\mathrm{a}} \times$ drought interactions. We simulated a $C_{\mathrm{a}} \times$ drought interaction in an experiment where plant leaf area increased in response to $\mathrm{e} C_{\mathrm{a}}$, fully compensating the lower water use per unit leaf area. MAESPA was able to simulate the decrease in soil water content and $\Psi_{\mathrm{L}}$ (Fig. 6a and b), after calibrating parameters related to stomatal conductance (Table 3) using the $\mathrm{a} C_{\mathrm{a}}$ treatment only. Using this parameter set, however, the measured $\Psi_{\mathrm{L}}$ was overestimated early in the dry-down for the $\mathrm{e}_{\mathrm{a}}$ treatment, and underestimated late in the drydown (Fig. 6b). The relative response of $E_{\mathrm{T}}$ to e $C_{\mathrm{a}}$ (Fig. 6) illustrates that the e $C_{\mathrm{a}}$ plants used more water early in the dry-down, which led to a more severe water stress, so that water use was substantially less under $\mathrm{e} C_{\mathrm{a}}$ towards the end of the dry-down. This response was also predicted by MAESPA 
(Fig. 6c), because $\Psi_{\mathrm{L}}$ was lower in the (simulated) e $C_{\mathrm{a}}$ treatment.

Using the calibrated model, it is possible to tease apart contributions of different mechanisms on the overall interaction between $C_{\mathrm{a}}$ and drought, by running simulations with different settings. For this experiment, we ran simulations exploring the contributions of changes in leaf area vs. changes in leaf-level water use. If plant leaf area was assumed unchanged between $\mathrm{a} C_{\mathrm{a}}$ and $\mathrm{e} C_{\mathrm{a}}$ treatments, we observed a very strong positive interaction between $C_{\mathrm{a}}$ and drought on $E_{\mathrm{T}}$, as expected from the baseline simulations (Fig. 6c, dashed line). If leaf area was assumed to increase in the e $C_{\mathrm{a}}$ treatment, but leaf-level water use was assumed not to change (dot-dashed line in Fig. 6c), $E_{\mathrm{T}}$ declined much more quickly, indicating that the leaf-level response to e $C_{\mathrm{a}}$ did have a substantial ameliorating effect on the response of $E_{\mathrm{T}}$ to drought.

Finally, we quantified the drought impact on total photosynthesis in the cherry experiment, by calculating total photosynthesis over the entire dry-down under different assumptions, and expressing it relative to simulated total photosynthesis under well-watered conditions (Fig. 7). At a $C_{\mathrm{a}}$, drought reduced total photosynthesis by $22 \%$. For the e $C_{\mathrm{a}}$ treatment, three simulations are summarized. The first two are calculated drought responses if leaf area is the same between $C_{\mathrm{a}}$ and e $C_{\mathrm{a}}$ treatments, and the third is the model prediction for the actual experimental conditions of the cherry experiment. The first simulation, Run 1, is the "baseline", which includes both the "water savings" and the " $C_{\mathrm{i}}$ effect" (see above). The second simulation, Run 2 , is at $\mathrm{a} C_{\mathrm{a}}$, but with reduced leaf area to match the pre-drought $\mathrm{e} C_{\mathrm{a}}$ water use, and therefore is equivalent to the water savings effect of $\mathrm{e} C_{\mathrm{a}}$. In the third simulation, Run 3, leaf area was increased similarly as in the cherry experiment, so that pre-drought water use was the same as in the $\mathrm{a} C_{\mathrm{a}}$. In the $C_{\mathrm{a}}$ simulations, drought reduced total photosynthesis by $10 \%$ (without feedbacks; Run 1), and $13 \%$ (Run 2, water savings only), respectively. With the leaf area feedback (Run 3), there was a larger reduction in total photosynthesis $(30 \%)$, which counteracted the positive interaction between $C_{\mathrm{a}}$ and drought. In summary, there was a positive e $C_{\mathrm{a}} \times$ drought interaction, because drought reduced photosynthesis less in $\mathrm{e} C_{\mathrm{a}}$ than in $\mathrm{a} C_{\mathrm{a}}$. This positive interaction was largely the result of the "water savings" effect, and disappears completely when leaf area is increased in $C_{\mathrm{a}}$, as was the case in the cherry experiment.

\section{Discussion}

We have presented a new soil-plant-atmosphere model, MAESPA, that can be applied to both individual plant and whole stand scales. The model includes detailed radiation transfer and leaf physiology routines from the MAESTRA model, and mechanistic water balance and hydraulics from
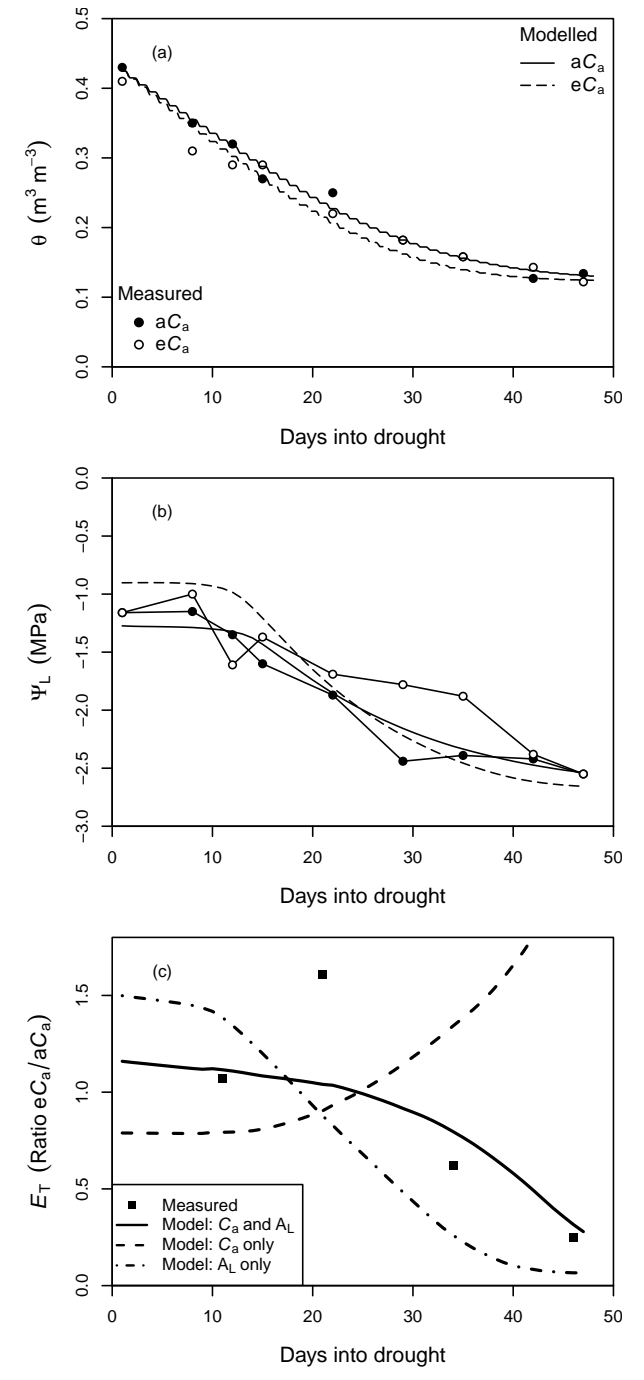

Fig. 6. Application of MAESPA to an experiment on droughted cherry seedlings by Centritto et al. (1999a, b). Model parameters were based on reported values in the original study, or calibrated to yield a satisfactory fit to the data of the $C_{\mathrm{a}}$ treatment only (see text and Table 2). The optimized parameter set was then used to predict water balance in the $C_{\mathrm{a}}$ treatment, and taking into account the observed increase in leaf area in the $C_{\text {a }}$ seedlings. (a) Decline in average soil water content over the rooting zone $(\theta)$ as the drought progressed. (b) Decline in the midday leaf water potential for sunlit foliage $\left(\Psi_{\mathrm{L}}\right)$. Note a relatively poor fit for the e $C_{\mathrm{a}}$ treatment: $\Psi_{\mathrm{L}}$ is over-predicted early in the drought, and under-predicted towards the end of the drought. (c) The ratio of total water use in $C_{\mathrm{a}}$ to $\mathrm{a} C_{\mathrm{a}}$ during the dry-down. Higher leaf area in $\mathrm{e} C_{\mathrm{a}}$ initially leads to higher water use, but this leads to lower $\theta$ (a) and $\Psi_{\mathrm{L}}$ (b), so that $\mathrm{e} C_{\mathrm{a}}$ seedlings were more water-stressed toward the end of the drydown than their a $C_{\mathrm{a}}$ counterparts. The solid line shows the simulations where e $C_{\mathrm{a}}$ and the increase in leaf area in the e $C_{\mathrm{a}}$ treatment were taken into account, dashed lines show either the direct $C_{\mathrm{a}}$ effect only (without leaf area feedback) or the leaf area feedback only (no e $C_{\mathrm{a}}$ treatment). 


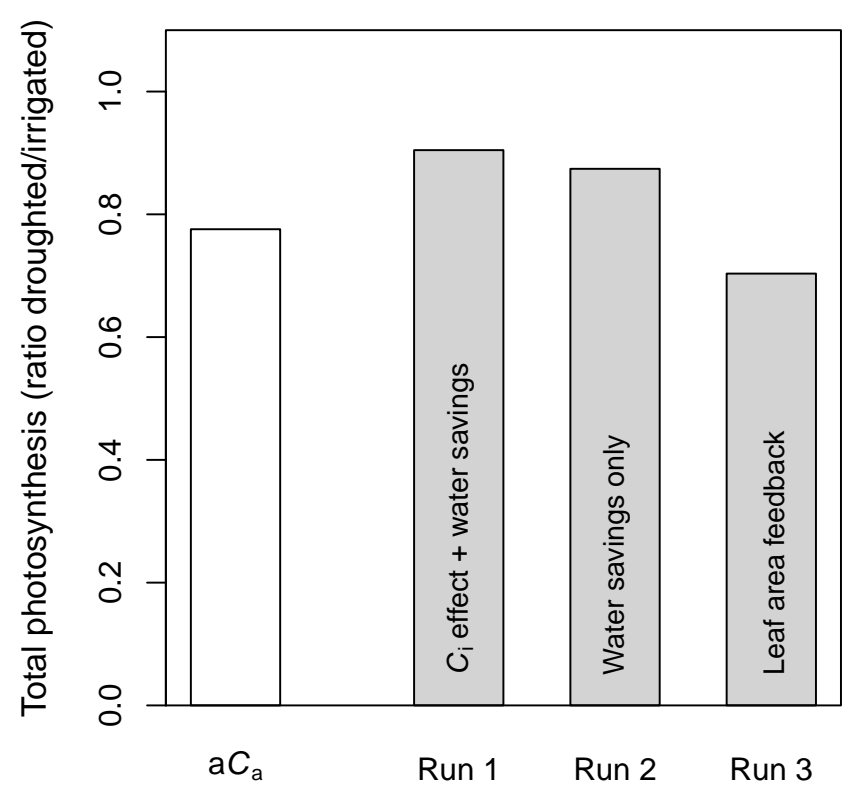

Fig. 7. Effect of the drought treatment on simulated total photosynthesis (summed over the entire 47 day simulation) for the dry-down in the cherry experiment (Fig. 6). The a $C_{\text {a }}$ simulation shows a $22 \%$ reduction in $A_{\mathrm{T}}$ in the dry-down treatment. For e $C_{\mathrm{a}}$, three simulations are shown. Run 1: full simulation but without the leaf area feedback, Run 2: simulation at $C_{\mathrm{a}}$, but with reduced leaf area to match total water use in the $C_{\mathrm{a}}$ simulation (Run 1), Run 3: including the observed leaf area increase in the $C_{\mathrm{a}}$ treatment.

the SPA model. We have shown that the model gives realistic predictions of the response of several plant variables to drought. As an example application, we used the model to study the interaction between atmospheric $\left[\mathrm{CO}_{2}\right]\left(C_{\mathrm{a}}\right)$ and drought.

\subsection{Understanding controls on the $C_{\mathrm{a}} \times$ drought interaction}

In this paper, we illustrated the use of the MAESPA model by quantifying interactions between $C_{\mathrm{a}}$ and drought under several potential experimental scenarios. First we simulated our "baseline" expectation of the $C_{\mathrm{a}} \times$ drought interaction, in the absence of feedbacks or acclimation of plant properties to long-term growth at e $C_{\mathrm{a}}$. Experimental outcomes can be compared to simulations like these, in order to evaluate whether the results are in quantitatively in line with current understanding of biophysical and physiological controls on whole-plant gas exchange and water balance.

The MAESPA model was able to simulate the effects of a soil dry-down on several variables in line with published observations. During the dry-down, $C_{\mathrm{i}} / C_{\mathrm{a}}$ steadily decreased, so that $A_{\mathrm{T}} / E_{\mathrm{T}}$ increased, which is consistent with published studies where non-stomatal limitations to carbon uptake are minimal (Brodribb, 1996). Midday leaf water potential $\left(\Psi_{\mathrm{L}}\right)$ decreased steadily, as typically observed (Sperry, 2000), and leaf temperature increased as a result of lower stomatal conductance in dry soil (Jones, 1992; Triggs et al., 2004). Finally, the depth of root water uptake gradually shifted to deeper layers (cf. Rambal, 1984; Duursma et al., 2011).

The baseline simulations predict that total $\mathrm{CO}_{2}$ uptake $\left(A_{\mathrm{T}}\right)$ is enhanced more by e $C_{\mathrm{a}}$ in dry soil (Fig. 5a), which is in line with previous predictions (Grossman-Clarke et al., 2001), and follows directly from the nonlinearity of the dependence of $A_{\mathrm{n}}$ on $C_{\mathrm{i}}$ (the " $C_{\mathrm{i}}$ effect"). The magnitude of this drought-enhanced $\mathrm{e} C_{\mathrm{a}}$ response depends on the parameters used (in particular $V_{\mathrm{cmax}}, g_{1}$ ), as well as the soil water content (Fig. 5a). Although many studies on agricultural crops have demonstrated that biomass growth or net canopy carbon uptake is more enhanced by e $C_{\mathrm{a}}$ during drought (Rogers et al., 1994), a great number of studies, particularly on trees, fail to demonstrate this effect (see Wullschleger et al., 2002; Nowak et al., 2004; Duursma et al., 2011; Warren et al., 2011). It should be noted that the interpretation of biomass growth in drought conditions is not straightforward because biomass growth may be temporally uncoupled from photosynthetic $\mathrm{CO}_{2}$ uptake (Körner, 2003; Sala and Hoch, 2009). However, this is unlikely an explanation for the lack of observations for expected $C_{\mathrm{a}} \times$ drought interaction in trees, because many studies report $\mathrm{CO}_{2}$ uptake as well as biomass growth. We showed here that two plant parameters, that are frequently observed to be affected by acclimation to $\mathrm{e} C_{\mathrm{a}}$, can reduce or even reverse this expected interaction (Fig. 6). Some studies have found this "reverse" response: Schäfer et al. (2002) found that, in a FACE study on Pinus taeda L., $E_{\mathrm{L}}$ was only reduced by e $C_{\mathrm{a}}$ when soil was dry, which counters the baseline expectation of $C_{\mathrm{a}}$ responses (Fig. 6). In a FACE study on Liquidambar styraciflua L., Gunderson et al. (2002) found a higher sensitivity of $g_{\mathrm{s}}$ to $\Psi_{\mathrm{S}}$ in e $C_{\mathrm{a}}$ trees, which also has the potential to reverse the expected interaction between $C_{\mathrm{a}}$ and drought. We need to quantify the effect of such leaf acclimation to $\mathrm{e} C_{\mathrm{a}}$ and investigate the degree to which it can explain experimental outcomes that diverge from baseline predictions. A model such as MAESPA is an essential tool to quantify the contribution of such mechanisms.

Baseline expectations are that lower leaf-level water use in $\mathrm{e} C_{\mathrm{a}}$ will lead to a higher soil water content, thus delaying the onset of drought (Morgan et al., 2004). A drought treatment should therefore have less impact on total carbon uptake in $\mathrm{e} C_{\mathrm{a}}$ than in an a $C_{\mathrm{a}}$ treatment, because drought stress is postponed (the "water savings" effect). However, testing this hypothesis against data from $C_{\mathrm{a}} \times$ drought experiments can be difficult because increased plant size in $\mathrm{e} C_{\mathrm{a}}$ often compensates for lower leaf-level water use, so that a clear "water savings" effect is often not directly observed (Morison and Gifford, 1984; Roden and Ball, 1996; Centritto et al., 1999a). We applied MAESPA to an experiment in cherry, where increased leaf area fully compensated for lower leaf-level water use. In this experiment, soil water content declined at similar rates in $\mathrm{a} C_{\mathrm{a}}$ and $\mathrm{e} C_{\mathrm{a}}$ treatments (Fig. 6), despite lower water use at the leaf-level in in $C_{\mathrm{a}}$, because leaf area was 
ca. $50 \%$ higher in the e $C_{\text {a }}$ plants. The MAESPA model successfully simulated the compensation of total plant water use by increased leaf area, using one parameter set for both $C_{\mathrm{a}}$ treatments, and the measured leaf areas. Because of the leaf area feedback, Centritto et al. (1999a) concluded that there was no positive interaction between drought and $C_{\mathrm{a}}$, a conclusion that followed from a standard empirical analysis of the results. Experiments like this can be further analysed in a quantitative framework like MAESPA, because plant leaf area can be quantitatively accounted for in the simulations, which is much more difficult to accomplish in a purely empirical analysis. Using the parameterized model, it is then possible to separate the various contributing factors to the overall $C_{\mathrm{a}} \times$ drought interaction, and to estimate the strength of the interaction between $C_{\mathrm{a}}$ and drought.

Using the parameterized MAESPA model, we showed that there were interactions between $C_{\mathrm{a}}$ and drought in the cherry experiment. As the drought progressed, total plant water use declined more rapidly in the $\mathrm{e} C_{\mathrm{a}}$ treatment (Fig. 6c), an experimental observation that was roughly matched by the model simulation (Fig. 6c). However, a poor fit to $\Psi_{\mathrm{L}}$ (Fig. 6b) was necessary to match the larger reduction in $E_{\mathrm{T}}$ in $\mathrm{e} C_{\mathrm{a}}$ as the dry-down progressed (Fig. 6c). This mismatch is possibly because $\Psi_{\mathrm{L}}$ was sampled on a few sunlit leaves that were not representative of the entire canopy. Without the leaf area feedback, there was a strong simulated positive interaction of $C_{\mathrm{a}}$ and drought (Fig. 6c): water use could continue much longer in the e $C_{\mathrm{a}}$ treatment due to initial water savings. This analysis was therefore able to separate effects of leaf area and leaf-level processes on the response of plant water use to drought and $C_{\mathrm{a}}$.

The interaction between $C_{\mathrm{a}}$ and drought is expected to particularly affect plant $\mathrm{CO}_{2}$ uptake $\left(A_{\mathrm{T}}\right)$, because of the " $C_{\mathrm{i}}$ effect": photosynthesis is more responsive to $C_{\mathrm{a}}$ at low stomatal conductance, as is the case during drought (Fig. 5a). But what is the expected strength of this interaction, and is it more important than the "water savings" effect? For the cherry experiment, we calculated total $A_{\mathrm{T}}$ over the entire drying cycle, and expressed it as a ratio of droughted to irrigated control (Fig. 7). Drought reduced total $A_{\mathrm{T}}$ by a smaller fraction in the $\mathrm{e} C_{\mathrm{a}}$ treatment compared to the $\mathrm{a} C_{\mathrm{a}}$ treatment (10\% vs. $23 \%)$. This relatively small difference is perhaps one reason that the $C_{\mathrm{a}} \times$ drought interaction in experiments is often not significant, because there may be insufficient power to detect effects of this size. The simulation analysis demonstrated that the positive interaction was mostly a water savings effect in this case, the " $C_{\mathrm{i}}$ effect" was very small (Fig. 7). It is possible that the $C_{\mathrm{i}}$ effect is larger in other experiments, because it depends on the shape of the $A-$ $C_{\mathrm{i}}$ curve, the degree of drought stress, stomatal conductance, and the length of the drought period.

Large scale simulations of $C_{\mathrm{a}}$ effects on vegetation water use and carbon uptake do not account for acclimation or feedbacks of plant processes to long-term growth at $C_{\mathrm{a}}$ (e.g. Cramer et al., 2001; Luo et al., 2008), and as such yield predictions of a positive $C_{\mathrm{a}} \times$ drought interaction in line with the baseline predictions shown here (Fig. 4). However, actual experimental outcomes yield varied results, making it difficult to inform model formulation and parameterization with experimental data. Here, we showed that by taking into account the observed feedback of plant leaf area in one experiment, it is possible to study the $C_{\mathrm{a}}$ effect on plant water use and carbon uptake, had the feedback not occurred. A model like MAESPA can also be used to evaluate alternative explanations for the deviation from experimental outcomes from the expected theory, such as acclimation of plant hydraulic parameters (e.g. $k_{\mathrm{P}}, \Psi_{f}$ ), and to evaluate whether responses at the leaf level match the responses at the whole-canopy scale.

\subsection{Possible applications of MAESPA}

While this study focussed on the interaction between $C_{\mathrm{a}}$ and drought, there are a number of possible applications of a soilplant-atmosphere model that can be applied to whole-plant and forest stand scales. Analysis of complex experiments where data are collected at leaf-level, whole-tree or canopy level, and in the soil, can be strengthened if all data are integrated in the parameterization of a soil-plant-atmosphere model (Williams et al., 2001b; Medlyn et al., 2005; Duursma et al., 2007, 2009). Because MAESPA can be applied to potted plants, it may be used to generalize experimental results from the vast number of experiments on potted plants, that are typically confounded by changes in plant size with experimental treatments (e.g. Damesin et al., 1996).

There is a growing interest in the effects of stand structure on ecosystem functioning, because the spatial distribution of leaf area index (LAI) in sparse or dense crowns affects radiation interception, energy balance, and total water use (Chen et al., 2008; Yang et al., 2010), even though LAI is the primary driver for fluxes of water and carbon. The MAESPA model is well suited to study effects of canopy structure and grouping of foliage in tree crowns on whole-canopy performance, and to evaluate simplified approaches.

All currently available soil-plant-atmosphere models can only be applied to entire canopies, restricting their use to studying stand-level processes. The advantage of MAESPA is that single plants can be studied. For example, models of vegetation water use are typically tested against scaled-up sap-flux measurements (Hanson et al., 2004; Williams et al., 2001a; Zeppel et al., 2008). An individual-based model such as MAESPA can be used to address questions of resource distribution among plants of different size and species within a canopy (cf. Binkley et al., 2010), in particular regarding the use of soil water and response to soil drought.

\subsection{Uncertainty in process representation}

The quantitative understanding of a number of processes in the soil-plant-atmosphere continuum is limited, so that 
improvements to models like MAESPA are certainly possible. Below, we discuss uncertainty in three components of MAESPA, but they apply to any soil-plant-atmosphere model: root water uptake, variation in plant hydraulic conductance, and non-stomatal limitations to $\mathrm{CO}_{2}$ uptake during drought. These three components are just examples where progress in process understanding will improve soil-plantatmosphere models; there are certainly others.

Predicting the distribution of root water uptake with depth in the soil is an old problem (Gardner, 1964), and surprisingly little progress has been made since the simple model advanced by Taylor and Keppler (1975), which is used in nearly all root water uptake models (Feddes et al., 2001). Although this approach seems relatively successful in predicting relative uptake of water from different soil layers (Markewitz et al., 2010), it is not useful in predicting the reduction in total water uptake when only a part of the root system is accessing wet soil, as is the case for chronically droughted trees that have few roots at great depth (Calder et al., 1997). A better understanding of the root hydraulic conductance and how it varies with depth in the soil, and the partitioning of the resistance between radial and longitudinal components of the root pathway are needed to improve on this model component.

It is typically assumed, as in MAESPA, that the decline in $\mathrm{CO}_{2}$ uptake during drought is the result only of reduced stomatal conductance, which simply limits the diffusion of $\mathrm{CO}_{2}$ into leaves. However, there is ample evidence that photosynthetic capacity $\left(A_{\mathrm{n}}\right.$ at a given $\left.C_{\mathrm{i}}\right)$ also declines during drought, albeit highly dependent on species and possibly only during more severe water stress (Lawlor and Cornic, 2002). Recently, Keenan et al. (2009) and Grant and Flanagan (2007) both showed that accounting for the reduction in photosynthetic capacity with drought stress improved model predictions of canopy fluxes. A more general understanding of non-stomatal limitations and how they develop during drought stress will improve models such as MAESPA.

In MAESPA, the hydraulic conductance of the plant pathway $\left(k_{\mathrm{P}}\right)$ does not decline during drought, and does not vary among shaded or sunlit portions of the canopy. Although $k_{\mathrm{P}}$ typically does decrease during drought due to formation of air-filled vessels (Sperry ,2000), Duursma et al. (2008) showed that a model assuming a fixed $k_{\mathrm{P}}$ was successful in predicting the response of plant water use to water limitation, in part because the soil resistance becomes limiting to water transport (Fisher et al., 2006). Nonetheless, gradual reduction in $k_{\mathrm{P}}$ during drought is often an important determinant of plant water use (Sperry et al., 1998; Hacke et al., 2000).

Differences in $k_{\mathrm{P}}$ between shaded and sunlit leaves in the canopy may exist because of shorter path length to shaded leaves, which increases $k_{\mathrm{P}}$ in shaded leaves relative to sunlit leaves (as assumed in the SPA model, Williams et al. ,1996), or more conductive tissues connecting sunlit leaves to the roots, which increases $k_{\mathrm{P}}$ in sunlit leaves (Lemoine et al., 2002). It is advantageous for plants to increase $k_{\mathrm{P}}$ to more productive parts of the crown (Katul et al., 2003), but it is as yet unclear how $k_{\mathrm{P}}$ actually varies within crowns. Recently, Peltoniemi et al. (2012) argued that it is optimal for plants to distribute total hydraulic conductance in a way that $k_{\mathrm{P}}$ is proportional to average PAR for any leaf in the canopy. If this hypothesis is confirmed with measurements, it greatly simplifies a difficult problem, and it can be readily implemented in MAESPA.

\subsection{Conclusions}

We have implemented a new tool to study single-plant or canopy-scale interactions between environmental drivers, canopy structure, weather, and soil water balance. The usefulness of a single-tree model has already been demonstrated by the broad user-base of the MAESTRA model. Here, we have widened the applicability by introducing detailed water balance components, and hydraulic constraints on water use and $\mathrm{CO}_{2}$ uptake. The new model incorporates a finer level of mechanistic detail than simplified water balance models (e.g. Granier et al., 1999), while still being relatively straightforward to parameterize (see Table B1 for a list of required parameters for the water balance component).

We suggest a way forward in integrating diverse experimental results, by evaluating experimental outcomes in a quantitative framework that summarizes our understanding of the soil-plant-atmosphere continuum. We showed that even relatively straightforward interactions like the $C_{\mathrm{a}} \times$ drought interaction can be highly variable, because they are dependent on feedbacks of plant size on the soil water balance and acclimation of plant properties due to long-term growth at $C_{\mathrm{a}}$. Quantitative evaluation of the role of such feedbacks is essential if we are to advance our understanding of plant responses to environmental change. Too often in the current literature on $C_{\mathrm{a}}$ experiments, responses are simply presented as significant/not significant, rather than being compared quantitatively to expectations based on current theory. As argued by Phillips and Milo (2009), we need to move from asking "Was there a change?" to asking "How large was the change, and is that what we expected?"

\section{Appendix A}

List of symbols, their definition and units. 
Table A1. List of symbols, their definition and units.

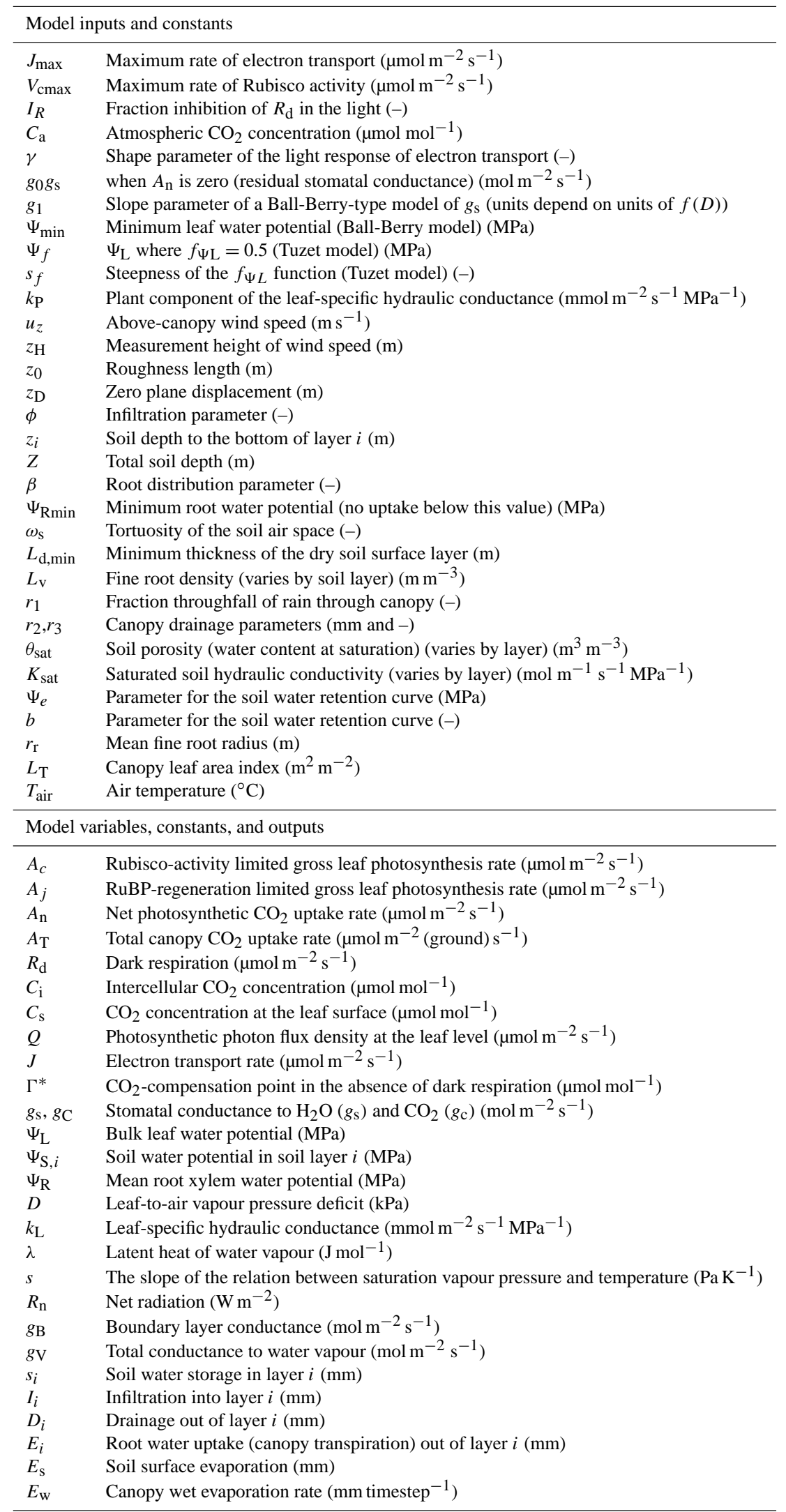


Table A1. Continued.

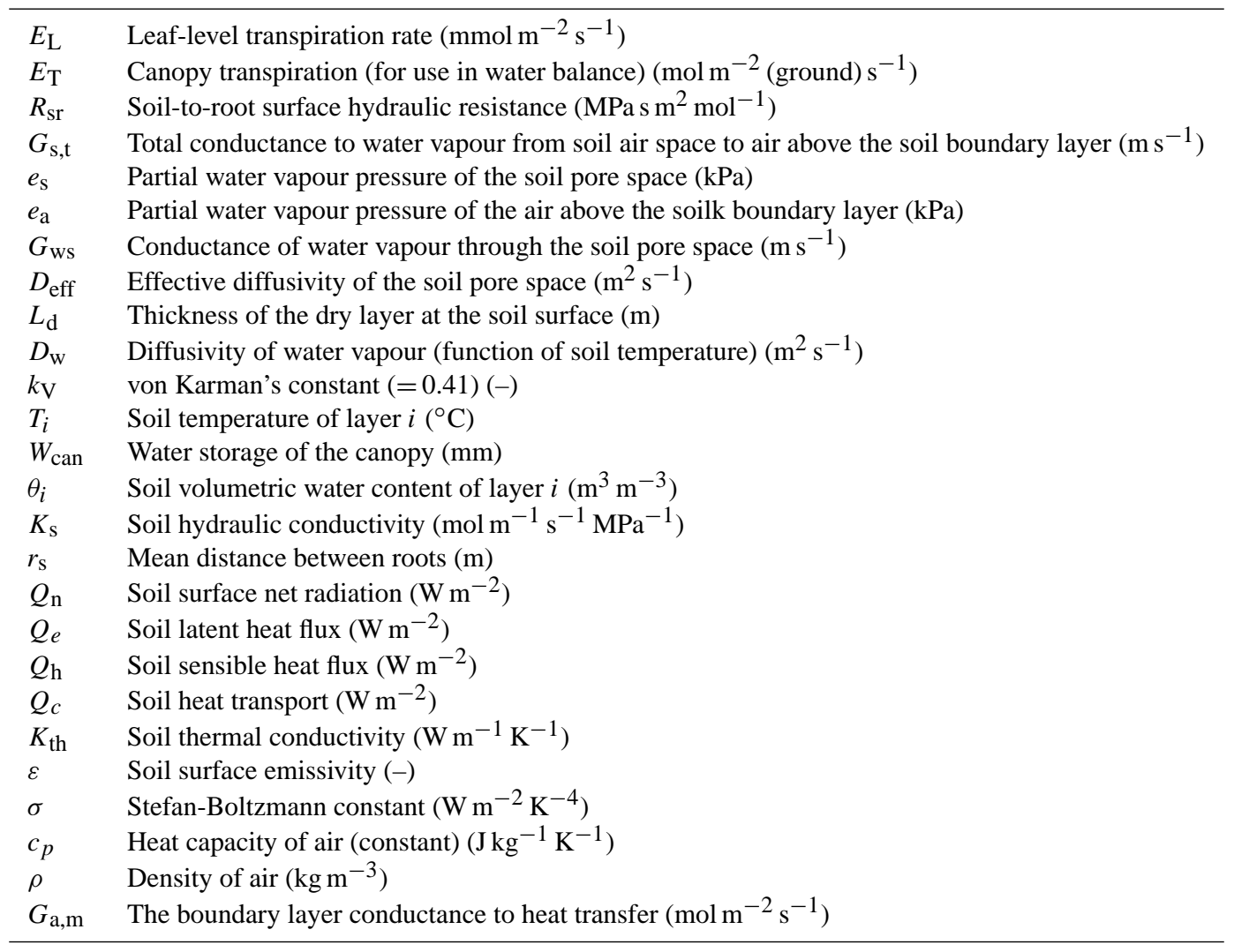

\section{Appendix B}

Below we have summarized the list of parameters needed to simulate the various components of the soil water balance and the response of plant water use to soil water deficit. Parameters that have very little influence or are likely to be near constant are not listed, nor are variables that are derived from the inputs and other constants. An example is fine root density, which has little influence on water uptake apart from the relative distribution of roots in different layers.
Table B1. List of parameters needed to simulate the water balance.

\begin{tabular}{|c|c|}
\hline$k_{\mathrm{P}}$ & $\begin{array}{l}\text { Plant component of the leaf-specific hydraulic } \\
\text { conductance }\left(\mathrm{mmol} \mathrm{m}^{-2} \mathrm{~s}^{-1} \mathrm{MPa}^{-1}\right)\end{array}$ \\
\hline$\Psi_{\min }$ & $\begin{array}{l}\text { Minimum leaf water potential (only when using } \\
\text { Ball-Berry model) (MPa) }\end{array}$ \\
\hline$\Psi_{f}$ & $\begin{array}{l}\Psi_{\mathrm{L}} \text { where } f_{\Psi L}=0.5 \text { (only when using Tuzet } \\
\text { model) }(\mathrm{MPa})\end{array}$ \\
\hline$s_{f}$ & $\begin{array}{l}\text { Steepness of the } f_{\Psi \mathrm{L}} \text { function (only when using } \\
\text { Tuzet model) (-) }\end{array}$ \\
\hline$Z$ & Total soil depth (m) \\
\hline$\beta$ & $\begin{array}{l}\text { Root distribution parameter (-) (or layer-wise } \\
\text { specification of rooting density) }\end{array}$ \\
\hline$r_{1}$ & Fraction throughfall of rain through canopy (-) \\
\hline$r_{2}, r_{3}$ & Canopy drainage parameters ( $\mathrm{mm}$ and - ) \\
\hline$\theta_{\text {sat }}$ & $\begin{array}{l}\text { Soil porosity (water content at saturation) (varies } \\
\text { by layer) }\left(\mathrm{m}^{3} \mathrm{~m}^{-3}\right)\end{array}$ \\
\hline$K_{\text {sat }}$ & $\begin{array}{l}\text { Saturated soil hydraulic conductivity (varies by } \\
\text { layer) }\left(\mathrm{mol} \mathrm{m}^{-1} \mathrm{~s}^{-1} \mathrm{MPa}^{-1}\right)\end{array}$ \\
\hline$\Psi_{e}$ & $\begin{array}{l}\text { Parameter for the soil water retention curve } \\
\text { (MPa) }\end{array}$ \\
\hline$b$ & Parameter for the soil water retention curve $(-)$ \\
\hline$\omega_{\mathrm{s}}$ & $\begin{array}{l}\text { Tortuosity of the soil air space (-) (only needed } \\
\text { for soil evaporation) }\end{array}$ \\
\hline$L_{\mathrm{d}, \min }$ & $\begin{array}{l}\text { Minimum thickness of the dry soil surface layer } \\
\text { (m) (only needed for soil evaporation) }\end{array}$ \\
\hline
\end{tabular}


Acknowledgements. We thank Mat Williams for providing the source code of the SPA model and encouraging a fusion with the MAESTRA model. RAD was supported by NSW Government Climate Action Grant (NSW T07/CAG/016). We thank Rhys Whitley for discussing SPA and Fortran, and Martin de Kauwe for additional coding and bug chasing.

Edited by: D. Lawrence

\section{References}

Ainsworth, E. A. and Long, S. P.: What have we learned from 15 years of free-air $\mathrm{CO}_{2}$ enrichment (FACE)? A meta-analytic review of the responses of photosynthesis, canopy properties and plant production to rising $\mathrm{CO}_{2}$, New Phytol., 165, 351-371, 2005.

Ainsworth, E. A. and Rogers, A.: The response of photosynthesis and stomatal conductance to rising $\left[\mathrm{CO}_{2}\right]$ : mechanisms and environmental interactions, Plant Cell Environ., 30, 258-270, doi:10.1111/j.1365-3040.2007.01641.x, 2007.

Atkinson, C. and Taylor, J.: Effects of elevated $\mathrm{CO}_{2}$ on stem growth, vessel area and hydraulic conductivity of oak and cherry seedlings, New Phytol., 133, 617-626, 1996.

Ball, J. T., Woodrow, I. E., and Berry, J. A.: A model predicting stomatal conductance and its contribution to the control of photosynthesis under different environmental conditions., in: Progress in photosynthesis research, edited by: Biggins, J., MartinusNijhoff Publishers, Dordrecht, the Netherlands, 221-224, 1987.

Barton, C. V. M., Ellsworth, D. S., Medlyn, B. E., Duursma, R. A., Tissue, D. T., Adams, M. A., Eamus, D., Conroy, J. P., McMurtrie, R. E., Parsby, J., and Linder, S.: Whole-tree chambers for elevated atmospheric $\mathrm{CO}_{2}$ experimentation and tree scale flux measurements in south-eastern Australia: The Hawkesbury Forest Experiment, Agr. Forest Meteorol., 150, 941-951, 2010.

Bauerle, W. L. and Bowden, J. D.: Separating foliar physiology from morphology reveals the relative roles of vertically structured transpiration factors within red maple crowns and limitations of larger scale models, J. Exp. Bot., 62, 4295-4307, 2011.

Berryman, C. A., Eamus, D., and Duff, G. A.: Stomatal responses to a range of variables in two tropical tree species grown with $\mathrm{CO}_{2}$ enrichment, J. Exp. Bot., 45, 539-546, doi:10.1093/jxb/45.5.539, 1994.

Binkley, D., Stape, J. L., Bauerle, W. L., and Ryan, M. G.: Explaining growth of individual trees: Light interception and efficiency of light use by Eucalyptus at four sites in Brazil, For. Ecol. Manage., 259, 1704-1713, 2010.

Bristow, K. L. and Campbell, G. S.: On the relationship between incoming solar radiation and daily maximum and minimum temperature, Agr. Forest Meteorol., 31, 159-166, 1984.

Brodribb, T.: Dynamics of changing intercellular $\mathrm{CO}_{2}$ concentration (ci) during drought and determination of minimum functional ci, Plant Physiol., 111, 179-185, 1996.

Calder, I. R., Rosier, P. T. W., Prasanna, K. T., and Parameswarappa, S.: Eucalyptus water use greater than rainfall input - possible explanation from southern India, Hydrol. Earth Syst. Sci., 1, 249256, doi:10.5194/hess-1-249-1997, 1997.

Campbell, G. S.: A simple method for determining unsaturated conductivity from moisture retention data, Soil Sci., 117, 311-314, 1974.
Centritto, M., Lee, H. S. J., and Jarvis, P. G.: Interactive effects of elevated $\left[\mathrm{CO}_{2}\right]$ and drought on cherry (Prunus avium) seedlings, I. Growth, whole-plant water use efficiency and water loss, New Phytol., 141, 129-140, 1999a.

Centritto, M., Magnani, F., Lee, H. S. J., and Jarvis, P. G.: Interactive effects of elevated $\left[\mathrm{CO}_{2}\right]$ and drought on cherry (Prunus avium) seedlings, II. Photosynthetic capacity and water relations, New Phytol., 141, 141-153, 1999b.

Chen, Q., Baldocchi, D., Gong, P., and Dawson, T.: Modeling radiation and photosynthesis of a heterogeneous savanna woodland landscape with a hierarchy of model complexities, Agr. Forest Meteorol., 148, 1005-1020, 2008.

Choudhury, B. J. and Monteith, J. L.: A four-layer model for the heat budget of homogeneous land surfaces, Q. J. Roy. Meteorol. Soc., 114, 373-398, 1988.

Comstock, J. and Mencuccini, M.: Control of stomatal conductance by leaf water potential in Hymenoclea salsola (T. \& G.), a desert subshrub, Plant, Cell Environ., 21, 1029-1038, doi:10.1046/j.1365-3040.1998.00353.x, 1998.

Cosby, B. J., Hornberger, G. M., Clapp, R. B., and Ginn, T. R.: A statistical exploration of the relationships of soil-moisture characteristics to the physical properties of soils, Water Resour. Res., 20, 682-690, 1984.

Cowan, I. and Farquhar, G. D.: Stomatal function in relation to leaf metabolism and environment, Sym. Soc. Exp. Biol., 31, 471505, 1977.

Cramer, W., Bondeau, A., Woodward, F. I., Prentice, I. C., Betts, R. A., Brovkin, V., Cox, P. M., Fisher, V., Foley, J. A., and Friend, A. D.: Global response of terrestrial ecosystem structure and function to $\mathrm{CO}_{2}$ and climate change: results from six dynamic global vegetation models, Glob. Change Biol., 7, 357-373, 2001.

Damesin, C., Galera, C., Rambal, S., and Joffre, R.: Effects of elevated carbon dioxide on leaf gas exchange and growth of corkoak (Quercus suber L) seedlings, Ann. Sci. For., 53, 461-467, 1996.

de Vries, D. A.: Thermal properties of soils, in: Physics of plant environment, edited by: van Wijk, W. R., Amsterdam, 210-235, 1963.

Delzon, S., Sartore, M., Burlett, R., Dewar, R. C., and Loustau, D.: Hydraulic responses to height growth in maritime pine trees., Plant, Cell Environ., 27, 1077-1087, 2004.

Domec, J.-C., Ogée, J., Noormets, A., Jouangy, J., Gavazzi, M., Treasure, E., Sun, G., McNulty, S. G., and King, J. S.: Interactive effects of nocturnal transpiration and climate change on the root hydraulic redistribution and carbon and water budgets of southern United States pine plantations, Tree Physiol., 32, 707-723, doi:10.1093/treephys/tps018, 2012.

Dubbe, D. R., Farquhar, G. D., and Raschke, K.: Effect of abscisic acid on the gain of the feedback loop involving carbon dioxide and stomata, Plant Physiol., 62, 413-417, 1978.

Duursma, R. A., Marshall, J. D., Robinson, A. P., and Pangle, R. E.: Description and test of a simple process-based model of forest growth for mixed-species stands, Ecol. Model., 203, 297-311, 2007.

Duursma, R. A., Kolari, P., Perämäki, M., Nikinmaa, E., Hari, P., Delzon, S., Loustau, D., Ilvesniemi, H., Pumpanen, J., and Mäkelä, A.: Predicting the decline in daily maximum transpiration rate of two pine stands during drought based on constant minimum leaf water potential and plant hydraulic conductance, 
Tree Physiol., 28, 265-276, 2008.

Duursma, R. A., Kolari, P., Perämäki, M., Pulkkinen, M., Mäkelä, A., Nikinmaa, E., Hari, P., Aurela, M., Berbigier, P., Bernhofer, C., Grünwald, T., Loustau, D., Mölder, M., Verbeeck, H., and Vesala, T.: Contributions of climate, leaf area index and leaf physiology to variation in gross primary production of six coniferous forests across Europe: a model-based analysis, Tree Physiol., 29, 621-639, 2009.

Duursma, R. A., Barton, C. V. M., Eamus, D., Medlyn, B. E., Ellsworth, D. S., Forster, M. A., Tissue, D. T., Linder, S., and McMurtrie, R. E.: Rooting depth explains $\left[\mathrm{CO}_{2}\right]$ ?×?drought interaction in Eucalyptus saligna, Tree Physiol., 31, 922-931, doi:10.1093/treephys/tpr030, 2011.

Eamus, D.: The interaction of rising $\mathrm{CO}_{2}$ and temperatures with water use efficiency, Plant, Cell Environ., 14, 843-852, 1991.

Eamus, D., Berryman, C., and Duff, G.: The Impact of $\mathrm{CO}_{2}$ Enrichment on Water Relations in Maranthes corymbosa and Eucalyptus tetrodonta, Aust. J. Bot., 43, 273-282, doi:10.1071/BT9950273, 1995.

Eguchi, N., Morii, N., Ueda, T., Funada, R., Takagi, K., Hiura, T., Sasa, K., and Koike, T.: Changes in petiole hydraulic properties and leaf water flow in birch and oak saplings in a $\mathrm{CO}_{2}$-enriched atmosphere, Tree Physiol., 28, 287-295, doi:10.1093/treephys/28.2.287, 2008.

Farquhar, G. D., Caemmerer, S., and Berry, J. A.: A biochemical model of photosynthetic $\mathrm{CO}_{2}$ assimilation in leaves of $\mathrm{C} 3$ species, Planta, 149, 78-90, 1980.

Feddes, R. A., Hoff, H., Bruen, M., Dawson, T., de Rosnay, P., Dirmeyer, O., Jackson, R. B., Kabat, P., Kleidon, A., Lilly, A., and Pitman, A. J.: Modeling root water uptake in hydrological and climate models, Bull. Am. Meteorol. Soc., 82, 2797-2809, 2001.

Federer, C., Vörösmarty, C., and Fekete, B.: Sensitivity of annual evaporation to soil and root properties in two models of contrasting complexity, J. Hydrometeorol., 4, 1276-1290, 2003.

Fisher, R. A., Williams, M., Do Vale, R. L., Da Costa, A. L., and Meir, P.: Evidence from Amazonian forests is consistent with isohydric control of leaf water potential, Plant Cell Environ., 29, 151-165, 2006.

Franks, P. J.: Stomatal control and hydraulic conductance, with special reference to tall trees, Tree Physiol., 24, 865-878, 2004

Gardner, W. R.: Dynamic aspects of water availability to plants, Soil Sci., 89, 63-73, 1960.

Gardner, W. R.: Relation of Root Distribution to Water Uptake and Availability, Agron. J., 56, 41-45, 1964.

Granier, A., Breda, N., Biron, P., and Villette, S.: A lumped water balance model to evaluate duration and intensity of drought constraints in forest stands, Ecol. Model., 116, 269-283, 1999.

Grant, R. F. and Flanagan, L. B.: Modeling stomatal and nonstomatal effects of water deficits on $\mathrm{CO} 2$ fixation in a semiarid grassland, J. Geophys. Res., 112, G03011, doi:10.1029/2006jg000302, 2007.

Grossman-Clarke, S., Pinter Jr., P., Kartschall, T., Kimball, B., Hunsaker, D., Wall, G., Garcia, R., and LaMorte, R.: Modelling a spring wheat crop under elevated $\mathrm{CO}_{2}$ and drought, New Phytol., 150, 315-335, 2001.

Gunderson, C. A., Sholtis, J. D., Wullschleger, S. D., Tissue, D. T., Hanson, P. J., and Norby, R. J.: Environmental and stomatal control of photosynthetic enhancement in the canopy of a sweetgum
(Liquidambar styraciflua L.) plantation during 3 years of $\mathrm{CO}_{2}$ enrichment, Plant Cell Environ., 25, 379-393, 2002.

Hacke, U. G., Sperry, J. S., Ewers, B. E., Ellsworth, D. S., Schafer, K. V. R., and Oren, R.: Influence of soil porosity on water use in Pinus taeda, Oecologia, 124, 495-505, 2000.

Hanson, P. J., Amthor, J. S., Wullschleger, S. D., Wilson, K. B., Grant, R. F., Hartley, A., Hui, D., Hunt, E. R., Johnson, D. W., Kimball, J. S., King, A. W., Luo, Y., McNulty, S. G., Sun, G., Thornton, P. E., Wang, S., Williams, M., Baldocchi, D. D., and Cushman, R. M.: Oak forest carbon and water simulations: Model intercomparisons and evaluations against independent data, Ecol. Monogr., 74, 443-489, 2004.

Heath, J., Kerstiens, G., and Tyree, M.: Stem hydraulic conductance of European beech (Fagus sylvatica L.) and pedunculate oak (Quercus robur L.) grown in elevated $\mathrm{CO}_{2}$, J. Exp. Bot., 48, 1487-1489, 1997.

Huntington, T. G.: Evidence for intensification of the global water cycle: Review and synthesis, J. Hydrol., 319, 83-95, 2006.

Jackson, R. B., Canadell, J., Ehleringer, J. R., Mooney, H. A., Sala, O. E., and Schulze, E. D.: A global analysis of root distributions for terrestrial biomes, Oecologia, 108, 389-411, 1996.

Jones, H. G.: Plants and microclimate: a quantitative approach to environmental plant physiology, 2nd Edn., Cambridge University Press, Cambridge, 428 pp., 1992.

Katul, G., Leuning, R., and Oren, R.: Relationship between plant hydraulic and biochemical properties derived from a steady-state coupled water and carbon transport model, Plant Cell Environ., 26, 339-350, 2003.

Keenan, T., García, R., Friend, A. D., Zaehle, S., Gracia, C., and Sabate, S.: Improved understanding of drought controls on seasonal variation in Mediterranean forest canopy $\mathrm{CO} 2$ and water fluxes through combined in situ measurements and ecosystem modelling, Biogeosciences, 6, 1423-1444, doi:10.5194/bg6-1423-2009, 2009.

Kirschbaum, M., King, D., Comins, H., McMurtrie, R., Medlyn, B., Pongracic, S., Murty, D., Keith, H., Raison, R., and Khanna, P. Modelling forest response to increasing $\mathrm{CO}_{2}$ concentration under nutrient-limited conditions, Plant, Cell Environ., 17, 1081-1099, 1994.

Körner, C.: Carbon limitation in trees, J. Ecol., 91, 4-17, 2003.

Kruijt, B., Barton, C., Rey, A., and Jarvis, P. G.: The sensitivity of stand-scale photosynthesis and transpiration to changes in atmospheric $\mathrm{CO}_{2}$ concentration and climate, Hydrol. Earth Syst. Sci., 3, 55-69, doi:10.5194/hess-3-55-1999, 1999.

Lawlor, D. and Cornic, G.: Photosynthetic carbon assimilation and associated metabolism in relation to water deficits in higher plants, Plant, Cell Environ., 25, 275-294, 2002.

Lemoine, D., Cochard, H., and Granier, A.: Within crown variation in hydraulic architecture in beech (Fagus sylvatica L): evidence for a stomatal control of xylem embolism, Ann. Forest Sci., 59, 19-27, 2002.

Leuning, R.: A Critical-Appraisal of a Combined StomatalPhotosynthesis Model for C-3 Plants, Plant Cell Environ., 18, 339-355, 1995.

Lu, S., Ren, T., Gong, Y., and Horton, R.: An improved model for predicting soil thermal conductivity from water content at room temperature, Soil Sci. Soc. Am. J., 71, 8-14, doi:10.2136/sssaj2006.0041, 2007. 
Luo, Y., Medlyn, B., Hui, D., Ellsworth, D., Reynolds, J., and Katul, G.: Gross primary productivity in duke forest: Modeling synthesis of $\mathrm{CO}_{2}$ experiment and eddy-flux data, Ecol. Appl., 11, 239252, 2001.

Luo, Y., Gerten, D., Le Maire, G., Parton, W. J., Weng, E., Zhou, X., Keough, C., Beier, C., Ciais, P., and Cramer, W.: Modeled interactive effects of precipitation, temperature, and $\left[\mathrm{CO}_{2}\right]$ on ecosystem carbon and water dynamics in different climatic zones, Glob. Change Biol., 14, 1986-1999, 2008.

Luxmoore, R. J., Hargrove, W. W., Tharp, M. L., Post, W. M., Berry, M. W., Minser, K. S., Cropper, W. P., Johnson, D. W., Zeide, B., and Amateis, R. L.: Signal-transfer modeling for regional assessment of forest responses to environmental changes in the southeastern united states, Environ. Model. Assess., 5, 125-137, 2000.

Manzoni, S., Vico, G., Katul, G., Fay, P. A., Polley, W., Palmroth, S., and Porporato, A.: Optimizing stomatal conductance for maximum carbon gain under water stress: a meta-analysis across plant functional types and climates, Funct. Ecol., 25, 456-467, doi:10.1111/j.1365-2435.2010.01822.x, 2011.

Markewitz, D., Devine, S., Davidson, E. A., Brando, P., and Nepstad, D. C.: Soil moisture depletion under simulated drought in the Amazon: impacts on deep root uptake, New Phytol., 187, 592-607, 2010.

McAdam, S. A. M., Brodribb, T. J., Ross, J. J., and Jordan, G. J.: Augmentation of abscisic acid (ABA) levels by drought does not induce short-term stomatal sensitivity to $\mathrm{CO}_{2}$ in two divergent conifer species, J. Exp. Bot., 62, 195-203, doi:10.1093/jxb/erq260, 2011.

McMurtrie, R. E., Norby, R. J., Medlyn, B. E., Dewar, R. C., Pepper, D. A., Reich, P. B., and Barton, C. V. M.: Why is plant-growth response to elevated $\mathrm{CO}_{2}$ amplified when water is limiting, but reduced when nitrogen is limiting? A growth-optimisation hypothesis, Funct. Plant Biol., 35, 521-534, doi:10.1071/FP08128, 2008.

Medlyn, B. E.: Interactive effects of atmospheric carbon dioxide and leaf nitrogen concentration on canopy light use efficiency: a modeling analysis, Tree Physiol., 16, 201-209, 1996.

Medlyn, B. E.: A MAESTRO Retrospective, in: Forests at the Land-Atmosphere Interface, edited by: Mencuccini, M., Grace, J., Moncrieff, J. B., and McNaughton, K., CAB International, 105-121, 2004.

Medlyn, B. E., Barton, C. V. M., Broadmeadow, M. S. J., Ceulemans, R., De Angelis, P., Forstreuter, M., Freeman, M., Jackson, S. B., Kellomaki, S., Laitat, E., Rey, A., Roberntz, P., Sigurdsson, B. D., Strassemeyer, J., Wang, K., Curtis, P. S., and Jarvis, P. G.: Stomatal conductance of forest species after long-term exposure to elevated $\mathrm{CO}_{2}$ concentration: a synthesis, New Phytol., 149, 247-264, 2001.

Medlyn, B. E., Dreyer, E., Ellsworth, D., Forstreuter, M., Harley, P. C., Kirschbaum, M. U. F., Le Roux, X., Montpied, P., Strassemeyer, J., Walcroft, A., Wang, K., and Loustau, D.: Temperature response of parameters of a biochemically based model of photosynthesis, II. A review of experimental data, Plant Cell Environ., 25, 1167-1179, 2002.

Medlyn, B. E., Berbigier, P., Clement, R., Grelle, A., Loustau, D., Linder, S., Wingate, L., Jarvis, P. G., Sigurdsson, B. D., and McMurtrie, R. E.: Carbon balance of coniferous forests growing in contrasting climates: Model-based analysis, Agr. Forest Meteorol., 131, 97-124, 2005.
Medlyn, B. E., Pepper, D. A., O'Grady, A. P., and Keith, H.: Linking leaf and tree water use with an individual-tree model, Tree Physiol., 27, 1687-1699, 2007.

Medlyn, B. E., Duursma, R. A., Eamus, D., Ellsworth, D. S., Prentice, I. C., Barton, C. V. M., Crous, K. Y., De Angelis, P., Freeman, M., and Wingate, L.: Reconciling the optimal and empirical approaches to modelling stomatal conductance, Glob. Change Biol., 17, 2134-2144, doi:10.1111/j.1365-2486.2010.02375.x, 2011.

Morgan, J., Pataki, D. E., Körner, C., Clark, H., del Grosso, S. J., Grunzweig, J. M., Knapp, A., Mosier, A. R., Newton, P. C. D., Niklaus, P. A., Nippert, J. B., Nowak, R. S., Parton, W. J., Polley, H. W., and Shaw, M. R.: Water relations in grassland and desert ecosystems exposed to elevated atmospheric $\mathrm{CO}_{2}$, Oecologia, 140, 11-25, 2004.

Morison, J. and Gifford, R.: Plant growth and water use with limited water supply in high $\mathrm{CO}_{2}$ concentrations, II. Plant dry weight, partitioning and water use efficiency, Funct. Plant Biol., 11, 375384, doi:10.1071/PP9840375, 1984.

Mott, K. A.: Do stomata respond to $\mathrm{CO}_{2}$ concentrations other then intercellular?, Plant Physiol., 86, 200-203, 1988.

Norby, R. and Luo, Y.: Evaluating ecosystem responses to rising atmospheric $\mathrm{CO}_{2}$ and global warming in a multi-factor world, New Phytol., 162, 281-293, 2004.

Norby, R. J., Wullschleger, S. D., Gunderson, C. A., Johnson, D. W., and Ceulemans, R.: Tree responses to rising $\mathrm{CO}_{2}$ in field experiments: implications for the future forest, Plant, Cell Environ., 22, 683-714, 1999.

Norman, J. M.: Modeling the complete crop canopy, in: Modification of the aerial environment of plants, edited by: Barfield, B. J., and Gerber, J. F., ASAE Monographs, American Soc. Agr. Eng., 2, 248-277, 1979.

Norman, J. M.: Scaling processes between leaf and canopy levels, in: Scaling physiological processes: leaf to globe, edited by: Ehleringer, J. R. and Field, C. B., Academic Press, San Diego, 41-76, 1993.

Norman, J. M. and Welles, J. M.: Radiative transfer in an array of canopies, Agron. J., 75, 481-488, 1983.

Nowak, R., Zitzer, S., Babcock, D., Smith-Longozo, V., Charlet, T., Coleman, J., Seemann, J., and Smith, S.: Elevated atmospheric $\mathrm{CO}_{2}$ does not conserve soil water in the Mojave Desert, Ecology, 85, 93-99, 2004.

Ogée, J., Lamaud, E., Brunet, Y., Berbigier, P., and Bonnefond, J. M.: A long-term study of soil heat flux under a forest canopy, Agr. Forest Meteorol., 106, 173-186, 2001.

Peltoniemi, M., Duursma, R. A., and Medlyn, B. E.: Cooptimal distribution of leaf nitrogen and hydraulic conductance in plant canopies, Tree Physiol., 32, 510-519, doi:10.1093/treephys/tps023, 2012.

Phillips, R. and Milo, R.: A feeling for the numbers in biology, Proc. Nat. Aca. Sci., 106, 21465-21471, doi:10.1073/pnas.0907732106, 2009.

Pierce, M. and Raschke, K.: Synthesis and metabolism of abscisic acid in detached leaves of Phaseolus vulgaris L. after loss and recovery of turgor, Planta, 153, 156-165, 1981.

Poorter, H. and Navas, M.: Plant growth and competition at elevated $\mathrm{CO}_{2}$ : on winners, losers and functional groups, New Phytol., 157, 175-198, 2003. 
Press, W. H., Teukolsky, S. L. A., Flannery, B. N. P., and Vetterling, W. M. T.: Numerical Recipes: FORTRAN, Cambridge university press, 1990.

R Development Core Team R: A language and environment for statistical computing. R Foundation for Statistical Computing, Vienna, Austria, ISBN 3-900051-07-0, available at: http://www. R-project.org/, 2011.

Rambal, S.: Water balance and pattern of root water uptake by a Quercus coccifera L. evergreen srub, Oecologia, 62, 18-25, 1984.

Reynolds, R. F., Bauerle, W. L., and Wang, Y.: Simulating carbon dioxide exchange rates of deciduous tree species: Evidence for a general pattern in biochemical changes and water stress response, Ann. Bot., 104, 775-784, doi:10.1093/aob/mcp156, 2009.

Roden, J. and Ball, M.: The effect of elevated $\left[\mathrm{CO}_{2}\right]$ on growth and photosynthesis of two eucalyptus species exposed to high temperatures and water deficits, Plant Physiol., 111, 909-919, 1996.

Rogers, H., Runion, G., and Krupa, S.: Plant responses to atmospheric $\mathrm{CO}_{2}$, enrichment with emphasis on roots and the rhizosphere, Environ. Pollut., 83, 155-189, 1994.

Rustad, L. R., Campbell, J. C., Marion, G. M., Norby, R. N., Mitchell, M. M., Hartley, A. H., Cornelissen, J. C., Gurevitch, J. G., and Gcte-News, G.-N.: A meta-analysis of the response of soil respiration, net nitrogen mineralization, and aboveground plant growth to experimental ecosystem warming, Oecologia, 126, 543-562, doi:10.1007/s004420000544, 2001.

Rutter, A. J., Morton, A. J., and Robins, P. C.: A predictive model of rainfall interception in forests, III. Generalization of the model and comparison with observations in some coniferous and hardwood stands, J. Appl. Ecol., 12, 367-380, 1975.

Sala, A. and Hoch, G.: Height-related growth declines in ponderosa pine are not due to carbon limitation, Plant Cell Environ., 32, 22-30, 2009.

Saxton, K. E. and Rawls, W. J.: Soil water characteristic estimates by texture and organic matter for hydrologic solutions, Soil Sci. Soc. Am. J., 70, 1569-1578, doi:10.2136/sssaj2005.0117, 2006.

Schäfer, K. V. R., Oren, R., Lai, C. T., and Katul, G. G.: Hydrologic balance in an intact temperate forest ecosystem under ambient and elevated atmospheric $\mathrm{CO}_{2}$ concentration, Glob. Change Biol., 8, 895-911, 2002.

Schaudt, K. J. and Dickinson, R. E.: An approach to deriving roughness length and zero-plane displacement height from satellite data, prototyped with BOREAS data, Agr. Forest Meteorol., 104, 143-155, 2000.

Schmidhalter, U.: The gradient between pre-dawn rhizoplane and bulk soil matric potentials, and its relation to the pre-dawn root and leaf water potentials of four species, Plant Cell Environ., 20, 953-960, 1997.

Sperry, J.: Hydraulic constraints on plant gas exchange, Agr. Forest Meteorol., 104, 13-23, 2000.

Sperry, J. S., Adler, F. R., Campbell, G. S., and Comstock, J. P.: Limitation of plant water use by rhizosphere and xylem conductance: results from a model, Plant Cell Environ., 21, 347-359, 1998.
Taylor, H. M. and Keppler, B.: Water uptake by cotton root systems: an examination of assumptions in the single root model, Soil Sci., 120, 57-67, 1975.

Triggs, J. M., Kimball, B. A., Pinter, P. J., Wall, G. W., Conley, M. M., Brooks, T. J., LaMorte, R. L., Adam, N. R., Ottman, M. J., Matthias, A. D., Leavitt, S. W., and Cerveny, R. S.: Free-air $\mathrm{CO}_{2}$ enrichment effects on the energy balance and evapotranspiration of sorghum, Agr. Forest Meteorol., 124, 63-79, 2004.

Tuzet, A., Perrier, A., and Leuning, R.: A coupled model of stomatal conductance, photosynthesis and transpiration, Plant Cell Environ., 26, 1097-1116, 2003.

Wang, Y. P. and Jarvis, P. G.: Description and validation of an array model - MAESTRO, Agr. Forest Meteorol., 51, 257-280, 1990.

Wang, Y. P. and Leuning, R.: A two-leaf model for canopy conductance, photosynthesis and partitioning of available energy I: Model description and comparison with a multi-layered model, Agr. Forest Meteorol., 91, 89-111, 1998.

Wang, Y. P., Jarvis, P. G., and Benson, M. L.: Two-dimensional needle-area density distribution within the crowns of Pinus radiata, For. Ecol. Manage., 32, 217-237, 1990.

Warren, J. M., Pötzelsberger, E., Wullschleger, S. D., Thornton, P. E., Hasenauer, H., and Norby, R. J.: Ecohydrologic impact of reduced stomatal conductance in forests exposed to elevated $\mathrm{CO}_{2}$, Ecohydrology, online first, doi:10.1002/eco.173, 2010.

Williams, M., Rastetter, E. B., Fernandes, D. N., Goulden, M. L., Wofsy, S. C., Shaver, G. R., Melillo, J. M., Munger, J. W., Fan, S. M., and Nadelhoffer, K. J.: Modelling the soil-plant-atmosphere continuum in a Quercus-Acer stand at Harvard forest: The regulation of stomatal conductance by light, nitrogen and soil/plant hydraulic properties, Plant Cell Environ., 19, 911-927, 1996.

Williams, M., Bond, B. J., and Ryan, M. G.: Evaluating different soil and plant hydraulic constraints on tree function using a model and sap flow data from ponderosa pine, Plant Cell Environ., 24, 679-690, 2001a.

Williams, M., Law, B. E., Anthoni, P. M., and Unsworth, M. H.: Use of a simulation model and ecosystem flux data to examine carbon-water interactions in ponderosa pine, Tree Physiol., 21, 287-298, 2001b.

Wu, Z., Dijkstra, P., Koch, G. W., Peñuelas, J., and Hungate, B. A.: Responses of terrestrial ecosystems to temperature and precipitation change: a meta-analysis of experimental manipulation, Glob. Change Biol., 17, 927-942, doi:10.1111/j.13652486.2010.02302.x, 2011.

Wullschleger, S. D., Tschaplinski, T. J., and Norby, R. J.: Plant water relations at elevated $\mathrm{CO}_{2}$ - implications for water-limited environments, Plant, Cell Environ., 25, 319-331, 2002.

Yang, W., Ni-Meister, W., Kiang, N. Y., Moorcroft, P. R., Strahler, A. H., and Oliphant, A.: A clumped-foliage canopy radiative transfer model for a Global Dynamic Terrestrial Ecosystem Model II: Comparison to measurements, Agr. Forest Meteorol., 150, 895-907, 2010.

Zeppel, M., Macinnis-Ng, C., Palmer, A., Taylor, D., Whitley, R., Fuentes, S., Yunusa, I., Williams, M., and Eamus, D.: An analysis of the sensitivity of sap flux to soil and plant variables assessed for an Australian woodland using a soil-plant-atmosphere model, Funct. Plant Biol., 35, 509-520, doi:10.1071/FP08114, 2008. 